\title{
RESPONSE OF MANGO TREES TO ORGANIC AND BIOFERTILIZERS IN NORTH SINAI
}

\author{
Sheren A. Abd El-Hamid ${ }^{1 *}$ and Mona M. El-Shazly ${ }^{2}$ \\ ${ }^{1}$ Department of Plant production, Desert Research Center, El- \\ Matareya, Cairo, Egypt \\ ${ }^{2}$ Department of Soil Fertility and Microbiology, Desert Research \\ Center, El-Matareya, Cairo, Egypt \\ *E-mail: sherenadel3m@yahoo.com
}

$\mathrm{T}$

his study was carried out during the two successive seasons of 2017 and 2018 on Sukkary mango trees budded on Sukkary rootstock, grown in sandy soil under drip irrigation system at Baloza district, North Sinai Governorate, Egypt. The aim of this study was to investigate the influence of using chicken manure or chicken manure tea as organic fertilizers combined with/without some bio fertilizes; mycorrhizae (Glomus macrocarbium), Azotobacter chroococcum and Bacillus circulans on improving yield and fruit quality characters of mango fruits (Sukari cv.). The chosen trees have been subjected to eleven treatments. The Chicken manure was added at $25 \mathrm{~kg} /$ tree in winter. While, chicken manure tea was added at $30 \mathrm{~L} /$ tree/season (divided into three equal doses; the first was added at growth start season and once every two months after the first) and also the bio fertilizes were applied three times parallel with the time of chicken manure tea treatments application. The obtained results indicated that chicken manure tea + mycorrhizae $+A$. chroococcum $+B$. circulans treatment increased leaf area, chlorophyll and nitrogen contents, fruit set, weight and number, total yield and vitamin $\mathrm{C}$ content and decreased fruit drop. Furthermore, chicken manure tea $+A$. chroococcum treatment increased leaf phosphorus and potassium content, fruit length, diameter, total soluble solids, total sugar and decreased fruit acidity. Application of bio fertilization treatments with chicken manure tea; chicken manure tea + mycorrhizae $+A$. chroococcum $+B$. circulans showed a positive effect on microbial determinations (total microbial counts, Azotobacter densities and Bacillus counts in the rhizosphere region of mango tree). On the other hand, the colonization percentage of mycorrhizae and number of spores/g soil attained higher values from using chicken manure fertilizers + mycorrhizae $+A$. chroococcum $+B$. circulans as compared to control. Also, this treatment showed an effective role in 
improving soil fertility via increasing NPK content, decreasing EC and a slight significant difference in $\mathrm{pH}$ values.

Keywords: mango, chicken manure, chicken manure tea, bio fertilization

Mango (Mangifera indica L.) is an important tropical fruit, ranking fifth among fruit production and consumption worldwide, and the third important promising fruit crop for export. Growing plants in the newly reclaimed soils faced various problems, such as low content of available nutrients and low organic matter content as well as poor hydrophilic, chemical and physical properties. The best means of maintaining soil fertility and productivity could be through periodic addition of organic manures, which can secure sustainable nutrients as the needs of the plants for growth and thrive. In addition, organic manures have been shown prominent promising improvement in soil physical conditions; such as moisture retention, aggregate soil stability, soil structure and fertility, controlling soil $\mathrm{pH}$ and providing the plants with mineral needs, formulations of other organic amendments help maintaining soil organic matter levels and crop performance (Hati et al., 2006). Organic manures are able to enhance soil microbial and enzyme activity by increasing soil microbial biomass (Sun et al., 2003 and Lu et al., 2005). So, farmers add organic manures fertilizers to improve soil fertility and to increase the yield of their crop. In addition, Hegazy et al. (2007) studied the effect of organic and bio-fertilization on vegetative growth and flowering of picual olive trees. They recorded that, $\mathrm{N}$ and $\mathrm{K}$ contents in leaf increased significantly with applying $100 \%$ poultry manure, but no significant difference was observed on leaf $\mathrm{P}$ content.

Compost tea is becoming increasingly popular amendment in organic agriculture, which is simply liquid solution form soaking compost in water (Litterick et al., 2004). Compost tea has an announced role in improving yield and fruit quality of fruit crops. This is attributed to the increase in the release of most nutrients due to this change from solid to liquid form. Using tea of all organic manures achieved many important functions when applied to the fruit crops at the optimum time and concentration. Moreover, the promotion of soil fertility and $\mathrm{N}$ fixation surely reflected on enhancing growth, yield and fruit quality. Also, Schmitz (2002) mentioned that compost tea is very rich in phytohormones and growth regulators. It stimulates the microorganisms that have a direct or indirect proper effect on the plant rhizosphere, besides, it optimizes the soil $\mathrm{pH}$ and their structure. Many investigators reported similar promotion effect of compost fertilizer on different plants; such as El-Sherbeny et al. (2007) on Ruta graveolens and Hendawy (2008) on Plantago arenaria. However, liquid organic fertilizers like chicken manure tea have been found to contain nitrogen mainly in inorganic form like ammonia (Gross et al., 2007) and can provide nutrients instantly to the plants much like the chemical fertilizers. These organisms may work by inducing plant resistance, inhibiting

Egyptian J. Desert Res., 69, No. 1, 39-66 (2019) 
pathogen growth or out-competing the pathogens. Some compost teas apparently contain large numbers of beneficial microbes that compete for space on leaves and fruits, denying pathogens space to colonize. Benefits described to the use of humic acid and related products to increase nutrient uptake, tolerance to drought and temperature extremes, the activity of beneficial soil microorganisms and availability of soil nutrients particularly in alkaline soils and low organic matter (Russo and Berlyn, 1990). Also, humic materials may increase root growth in a similar manner to auxins (Tatini et al., 1991). These water extractable components include active microorganisms, primarily bacteria, fungi and some protozoa.

Microorganisms in the soil are important because they maintain homeostasis environmental. They decompose organic material, recycle nutrients, remove some pollutants, stave off pathogens and release some potentially unavailable nutrients (Thies, 2008). Negi et al. (2011) stated that the use of plant growth promoters being cost-effective and eco-friendly is getting popular especially among the marginal and small farmers. Al-Erwy et al. (2016) added that, the application of plant growth promoters enhances the yield and nutritive value of various crops. Soil ecosystems are the most diverse compared to any other systems. Soil can contain more than $10^{9}$ microbial cells per gram and harbor up to $10^{6}$ different bacterial species per gram (Zhao et al., 2011). Other studies estimated that there may be close to 277,000 bacterial genomes per gram of soil (Thies, 2008). It has been shown that bacterial populations found in soils are positively influenced (i.e. found in greater abundance) from management practices that include residue incorporation compared to those in soils that are left alone (Davari et al., 2012).

Biofertilization of fruit crops drew the attention of pomologists in the last few decades to become an effective alternative to chemical fertilizers. Biofertilizers are very safe for human, animal and environment (Abd-Elmotty and Fawzy, 2005). Biofertilizers are biological containing primarily potent strains of microorganisms in sufficient number. These microorganisms have a definite beneficial role in the fertility of soil rhizosphere. In addition, biofertilizers contained bacteria led to increasing plant dry weight, leaf chlorophyll and net assimilation rate (El-Gamal, 1996). Also, inoculation with biofertilizers helps in the availability of minerals and their forms in the composted material and increases the level of extractable N, P, K, Fe, Zn and Mn (El-Kramany et al., 2000). Application of biofertilizers was favorable in improving growth, nutritional status of the trees, the yield as well as physical and chemical characteristics of mango trees (Abd-Elmotty and Fawzy, 2005).

The use of bio-fertilizers is very important for economical production. Azotobacter species are free-living bacteria, which grow well on a nitrogenfree medium and utilize atmospheric nitrogen gas for their cell protein synthesis. This cell protein is then mineralized in soil, Azotobacter cells thereby contributing to the nitrogen availability of the crop plants thus 
resulting in a strong symbiotic relationship. The beneficial effect of symbiotic nitrogen fixer Azotobacter chroococcum as free living $\mathrm{N}_{2}$ - fixing is attributed to fix atmospheric nitrogen, synthesis of phytohormones and vitamins, inhibiting plant ethylene synthesis, enhancing stress resistance and improving nutrient uptake (Massoud et al., 2013). Also release some compounds like auxins, cytokinin, and antibiotics improving growth and productivity of the crops. The results of Sarhan (2008) indicated a positive effect of Azotobacter on growth and yield of potato plants. Also, Azotobacter acts as plant growth promoters, when it converts unavailable minerals and organic compounds into forms available to plants. In addition, it increases plant growth and yield (Soliman et al., 2015). The population of Azotobacter in soil is mostly influenced by other micro-organisms present in the soil.

Arbuscular mycorrhizal fungi (AMF) have the ability to form symbiotic association with plants that benefit both partners through acquisition and absorption of nutrient, especially phosphorus from the soil (Barea et al., 2011). AM fungi interact with other soil microbes like free nitrogen fixer and promote biochemical cycling of elements to the host plants. These mycorrhizal symbionts occur in almost all fruit tree species grown in the nursery or open field (Calvet, 2004). AM fungi can establish extraradical mycelia, which disperse outside the roots to have access to a greater quantity of water and soil minerals for the host plants. The fungi receive plant carbohydrates for the completion of their life cycle (Hause and Fester 2005). Salinas et al. (2005) stated that vesicular-arbuscular species could supplement or replace chemical fertilizers of crops in varying environmental conditions. AM associations have been shown to reduce damage caused by soil-borne plant pathogens. This prophylactic ability of AM fungi could be exploited in cooperation with other rhizospheric microbial antagonists to improve plant growth and health (Hause and Fester, 2005). It is well documented that AM symbiosis can increase plant growth and nutrient uptake, improve fruit quality and alleviate several abiotic stresses; such as low-temperature stress, drought, salt stress, etc. (Miransari, 2010).

Among all plant growth promoters, Bacillus spp. has been reported to have tolerance towards the adverse conditions and therefore, the most potential candidate is used for enhancing the soil fertility and crop health (Vivas et al., 2003). Bacillus spp. is also known to enhance of macro- and micronutrients in the soil and their uptake by host plant (Stefan et al., 2013).

The aim of this study was to investigate the influence of chicken manure or chicken manure tea as organic fertilizers combined with/without bio fertilizes (mycorrhiza, Azoctobactir, B. circulans) to improve the fruit yield and quality characters of mango fruits cv. Sukari.

Egyptian J. Desert Res., 69, No. 1, 39-66 (2019) 


\section{MATERIALS AND METHODS}

This study was carried out during two successive seasons of 2017 and 2018 on 66 Sukkary mango trees of 10- years old, spaced 5 x $5 \mathrm{~m}$ apart, budded on Sukkary rootstock grown in sandy soil (Table 1) and irrigated by drip irrigation system (Table 2) at Baloza district, in North Sinai Governorate, Egypt. Selected trees were uniform in vigor as possible. Fertilization program and other agricultural practices were the same for all trees (except organic fertilization). The experiment was arranged in a complete randomized block design in three replicates and two trees for each.

Eleven treatments were conducted as follows:

$\left(\mathrm{T}_{1}\right)$ Control (treatment farm) as orchard practices

$\left(T_{2}\right)$ Chicken manure fertilizers

$\left(\mathrm{T}_{3}\right)$ Chicken manure fertilizers + mycorrhizae

$\left(\mathrm{T}_{4}\right)$ Chicken manure fertilizers + A. chroococcum

$\left(\mathrm{T}_{5}\right)$ Chicken manure fertilizers + B. circulans

$\left(\mathrm{T}_{6}\right)$ Chicken manure fertilizers + mycorrhizae + A. chroococcum $+B$. circulans

$\left(\mathrm{T}_{7}\right)$ Chicken manure tea

$\left(\mathrm{T}_{8}\right)$ Chicken manure tea + mycorrhizae

$\left(\mathrm{T}_{9}\right)$ Chicken manure tea + A. chroococcum

$\left(\mathrm{T}_{10}\right)$ Chicken manure tea $+B$. circulans

$\left(\mathrm{T}_{11}\right)$ Chicken manure tea + mycorrhizae + A. chroococcum $+B$. circulans

Table (1). Chemical and physical properties of the experimental soil.

\begin{tabular}{|c|c|c|c|c|c|c|c|c|c|c|c|c|c|}
\hline \multicolumn{3}{|c|}{$\begin{array}{c}\text { Particle size } \\
\text { distribution } \\
(\%)\end{array}$} & \multirow[t]{2}{*}{$\begin{array}{c}\text { Soil } \\
\text { texture }\end{array}$} & \multirow[t]{2}{*}{$\begin{array}{c}\text { EC } \\
(\mathrm{dS} / \mathrm{ml})\end{array}$} & \multirow[t]{2}{*}{ pH } & \multicolumn{4}{|c|}{ Soluble cations meq/l } & \multicolumn{4}{|c|}{ Soluble anions meq/l } \\
\hline Sand & Silt & Clay & & & & $\mathbf{K}^{+}$ & $\mathbf{N a}^{+}$ & $\mathbf{C a}^{+2}$ & $\mathrm{Mg}^{+2}$ & $\mathrm{CO}_{2}{ }^{3-}$ & $\mathrm{HC}^{3-}$ & $\mathrm{Cl}^{-}$ & $\mathrm{SO}_{2}{ }^{4-}$ \\
\hline 95 & 5 & - & Sandy & 2.67 & 7.9 & 1.0 & 16.65 & 5.3 & 3.8 & - & 3.85 & 14.3 & 8.6 \\
\hline
\end{tabular}

Table (2). Chemical analysis of irrigation water.

\begin{tabular}{cccccccccccc}
\hline \multirow{2}{*}{ Samples } & \multirow{2}{*}{$\begin{array}{c}\text { pH } \\
\text { E.C. }\end{array}$} & \multirow{2}{*}{ S.A.Rm) } & \multicolumn{3}{c}{ Soluble cations (me/l) } & \multicolumn{3}{c}{ Soluble anions (me/l) } \\
\cline { 4 - 11 } & & $\mathbf{C a}^{++}$ & $\mathbf{M g}^{++}$ & $\mathbf{N a}^{+}$ & $\mathbf{K}^{+}$ & $\mathbf{C O}^{2-}$ & $\mathbf{H C O}_{3}^{-}$ & $\mathbf{S O}_{4}{ }^{-}$ & $\mathbf{C l}^{-}$ \\
\hline & 7.49 & 1462 & 3.74 & 2.86 & 3.24 & 8.55 & 0.58 & 0.11 & 5.58 & 2.13 & 7.41 \\
\hline
\end{tabular}

Chicken manure fertilizers were added at $25 \mathrm{~kg} /$ tree in winter. While, chicken manure tea was added at $30 \mathrm{~L} /$ tree/season (divided into three equal doses) the first at growth start season and each of the other two doses was added every two months and also the bio fertilizes (mycorrhizae $50 \mathrm{~g} /$ tree, Azotobacter $500 \mathrm{ml} /$ tree and B. circulans $500 \mathrm{ml} /$ tree) were added three times parallel with the time of chicken manure tea treatments application. 


\section{Chicken Manure Tea Preparation}

Chicken manure tea was prepared by brewing of chicken manure and water at a ratio of $1: 5 \mathrm{w} / \mathrm{v}$ (chicken manure: water) supplemented with $2 \%$ molasses to stimulate microbial growth and continuous aeration for $24 \mathrm{~h}$ (Naidu et al., 2010). After that, manure tea was filtrated.

Microbial populations in the chicken manure and chicken manure tea, which were total microbial counts on nutrient agar (Nautiyal, 2000), aerobic $\mathrm{N}_{2}$-fixing bacteria on Ashby modified medium and incubated at $30^{\circ} \mathrm{C}$ for 7 days using the most probable number (MPN) technique of Atlas (2004), total fungi on Martin's Rose bengal agar (Atlas, 2004) and total coliforms, were determined using plate count or most probable number (MPN) technique APHA 1995. Chemical and biological properties of the chicken manure and chicken manure tea are presented in table (3).

Table (3). Chemical and biological properties of the chicken manure tea.

\begin{tabular}{lcc}
\hline Parameter & $\begin{array}{c}\text { Chicken } \\
\text { manure }\end{array}$ & $\begin{array}{c}\text { Chicken } \\
\text { manure tea }\end{array}$ \\
\hline $\mathbf{p H}$ & 8.42 & 7.92 \\
$\mathbf{E C}(\mathbf{d S} / \mathbf{m l})$ & 9.25 & 3.20 \\
$\mathbf{N}(\mathbf{\%})$ & 3.40 & 2.89 \\
$\mathbf{P}(\mathbf{\%})$ & 1.54 & 1.38 \\
$\mathbf{K}(\%)$ & 2.20 & 5.42 \\
Total microbial counts & $>300.00$ & $>300.00$ \\
$\times \mathbf{1 0} \mathbf{c f u} / \mathbf{g}$ & & \\
Total Fungi counts $\times \mathbf{1 0}^{\mathbf{2}} \mathbf{c f u} / \mathbf{g}$ & 31.00 & 9.00 \\
$\mathbf{N}_{\mathbf{2}}$ fixing bacteria $\times \mathbf{1 0}^{4} \mathbf{c f u} / \mathbf{g}$ & 45.00 & 68.00 \\
Total coliforms $(\mathbf{M P N} / \mathbf{1 0 0} \mathbf{~ m l})$ & ${ }^{*} \mathrm{ND}$ & ${ }^{*} \mathrm{ND}$ \\
\hline *ND: not detected & &
\end{tabular}

The following parameters were measured for both seasons:

- Leaf area: was measured using leaf area meter.

- Average total chlorophyll content: leaves were tested at the end of August in the field using Minolta meter SPAD.

- Macro and micronutrients: ten tagged leaves at each main direction from each tree were collected carefully at random at the end of September in both seasons. Total nitrogen content was determined in the dry weight using micro-kjeldahl method as described by Huphries (1959). Phosphorus content was colourimeterically determined by using ascorbic acid, according to the method described by John (1970). Potassium content was determined by using flamephotometer as described by Page et al. (1982).

- Fruit set (\%) was calculated as follows:

average fruits number per panicle / average perfect flowers number per panicle x 100

Egyptian J. Desert Res., 69, No. 1, 39-66 (2019) 
- Fruit drop (\%) was calculated as follows:

total number of setting fruits - number of retained fruits / total number of setting fruits $\mathrm{x} 100$

- Yield: The fruit weight/ tree $(\mathrm{kg})$ was recorded.

- Number of fruits per tree: was recorded at harvesting time (first week of August) for all treatments in both seasons.

- Fruit parameters: fruits samples were collected at the harvesting time (first week of August) to be used for determining the physical properties; i.e. fruit length $(\mathrm{cm})$, fruit diameter $(\mathrm{cm})$ and fruit weight $(\mathrm{g})$.

- Fruit quality: a sample of 10 ripe fruits of each tree collected at the harvest time to be used for determining the physical and chemical properties; i.e. the total soluble solids percentage (TSS\%) was measured by using a hand refractometer and the acidity (\%) as citric acid content using fresh juice with titration against $0.1 \mathrm{NaOH}$. The total sugars (\%), and vitamin $\mathrm{C}$ content according to A.O.A.C. (1985) were determined.

- Soil nutrient contents: before applying the treatments and at the end of the experiment, soil samples were taken from each treatment at major root zone $(0-60 \mathrm{~cm}$ depth) before and after. Nitrogen content was determined in the dry weight using micro-kjeldahl method as described by Huphries (1959). Phosphorus content was colourimeterically determined by using ascorbic acid according to the method described by John (1970). Potassium content was determined by using flamephotometer as described by Page et al. (1982).

\section{Isolation, Purification of Bacterial Isolates from Study Area}

Different soil samples were collected from different locations at the study area for isolation of Azotobacter and phosphate dissolving bacteria (PDB). Purification trials were carried out and purified isolates were maintained for further study.

\section{Screening Biochemical Activity of Microbial Isolates}

Obtained isolates were examined for $\mathrm{N}_{2}$ fixation according to modified Kjeldahl method after Page et al. (1982) for Azotobacter isolates and phosphate solubilization (Goenadi et al., 2000), for Bacillus isolates. The most active isolates were selected and identified using 16S rRNA genes sequencing.

\section{Identification of Bacterial Isolates}

The genomic DNA was isolated according to Sambrook and Russel (2001). Amplification of 16S rRNA gene of BPR7 was carried out by PCR (PTC 100, M.J. Research, USA) using universal eubacterial primers FD1 5 CCG AAT TCG TCG ACA ACA GAG TTT GAT CCT GGC TC AG 3_and 
RD1 5_ CCC GGG ATC CAA GCT TAA GGA GGT GAT CCA GCC 3 (Weisburg et al., 1991). Similarity, 16S rRNA gene sequence was aligned using BLAST programme of GenBank database (NCBI).

Identified isolates were found to be similar to Azotobacter chroococcum and Bacillus circulans and kept, then used for the field experiment.

Fresh liquid culture of A. chroococcum and Bacillus circulans were used for single soil inoculation at the rate of $10^{8}$ colony forming unit $(\mathrm{cfu}) / \mathrm{ml}$ or in combinations with AM.

Mycorrhizal inoculum containing extrametrical hyphae, spores and root fragments of maize infected with Glomus macrocarbium grown for three months was used as soil inoculums.

\section{Total Microbial Counts in Rhizosphere Soil}

Rhizosphere soil samples were collected and analyzed for total count of microorganisms according to Nautiyal (2000). Counting and growing phosphate dissolving bacteria was carried out using Pikovskaya's agar medium (PVK) (Goenadi et al., 2000). For counting and growing Azotobacters, modified Ashby's media was used (Hill, 2000). Mycorrhizal root colonization percent were determined as follow:

Mycorrhizal Root colonization (\%) =

Total number of segments observed $\times 100$

Number of AM positive segments

\section{Statistical Analysis}

Data were subjected to analysis of variance. Duncan's multiple range test was used to differentiate means as described by Duncan (1955).

\section{RESULTS AND DISCUSSION}

\section{Leaf Area and Leaf Total Chlorophyll}

Data presented in table (4) show that all treatments were significantly effective on mango leaf area and total chlorophyll. However, application of $\mathrm{T}_{11}$ increased leaf area $\left(111.45 \mathrm{~cm}^{2}\right.$ in the first season and $112.22 \mathrm{~cm}^{2}$ in the second season) and total chlorophyll (48.36 and 49.01 in both seasons, respectively), followed by $\mathrm{T}_{9}$ in both seasons. While, $\mathrm{T}_{1}$ gave the lowest leaf area $\left(80.97 \mathrm{~cm}^{2}\right.$ in the first season and $85.79 \mathrm{~cm}^{2}$ in the second season) and total chlorophyll (40.01 and 40.3249 .01 in both seasons, respectively).

These effects of manure tea on plant growth may be related to the important role of nitrogen, phosphorus and potassium in plant tissues, which reflects on its vegetative growth. They play a vital role in photosynthesis, carbohydrate transport, protein formation, control of ionic balance, regulation of plant stomata and water use activation of plant enzymes and other processes (El-Dissoky, 2008). Compost tea contains all of the three major nutrients in

Egyptian J. Desert Res., 69, No. 1, 39-66 (2019) 
available forms for plants nutrition through its application. Gross et al. (2007) found that ammonium was the major form of nitrogen present in the extract solutions from all manure types and that the nitrogen released after extraction by the different methods from the different manures ranged between 50 and $85 \%$. This result confirms that organic liquid fertilizers like compost tea contain instant plant nutrients. Biofertilizers are known to increase the nitrogen fixation and nutrient content of soil (Babita and Thakur, 2015), produce growth stimulants for plants, improve soil stability, provide biological control, biodegrade substances, recycle nutrients and promote mycorrhizae symbiosis (Rivera-Cruz et al., 2008).

Table (4). Effect of organic and bio fertilizers on leaf area and leaf chlorophyll of mango trees during 2017 and 2018 seasons.

\begin{tabular}{ccccc}
\hline *Treatments & \multicolumn{2}{c}{$\begin{array}{c}\text { Leaf area } \\
\left(\mathbf{c m}^{2}\right)\end{array}$} & \multicolumn{2}{c}{$\begin{array}{c}\text { Leaf total chlorophyll } \\
\text { content }\end{array}$} \\
\cline { 2 - 5 } & $\mathbf{2 0 1 7}$ & $\mathbf{2 0 1 8}$ & $\mathbf{2 0 1 7}$ & $\mathbf{2 0 1 8}$ \\
\hline $\mathbf{T}_{\mathbf{1}}$ & $80.97 \mathrm{k}$ & $85.79 \mathrm{j}$ & $40.01 \mathrm{i}$ & $40.32 \mathrm{k}$ \\
$\mathbf{T}_{\mathbf{2}}$ & $85.67 \mathrm{j}$ & $88.220 \mathrm{i}$ & $41.04 \mathrm{~h}$ & $41.12 \mathrm{j}$ \\
$\mathbf{T}_{\mathbf{3}}$ & $90.18 \mathrm{~h}$ & $91.77 \mathrm{~g}$ & $42.11 \mathrm{f}$ & $42.04 \mathrm{~h}$ \\
$\mathbf{T}_{\mathbf{4}}$ & $105.65 \mathrm{~d}$ & $109.12 \mathrm{c}$ & $45.78 \mathrm{c}$ & $45.87 \mathrm{~d}$ \\
$\mathbf{T}_{\mathbf{5}}$ & $96.43 \mathrm{f}$ & $100.87 \mathrm{e}$ & $43.36 \mathrm{e}$ & $43.98 \mathrm{f}$ \\
$\mathbf{T}_{\mathbf{6}}$ & $108.20 \mathrm{c}$ & $110.47 \mathrm{~b}$ & $46.88 \mathrm{~b}$ & $46.99 \mathrm{c}$ \\
$\mathbf{T}_{\mathbf{7}}$ & $87.42 \mathrm{i}$ & $90.25 \mathrm{~h}$ & $41.66 \mathrm{~g}$ & $41.98 \mathrm{i}$ \\
$\mathbf{T}_{\mathbf{8}}$ & $91.28 \mathrm{~g}$ & $96.07 \mathrm{f}$ & $42.99 \mathrm{e}$ & $42.56 \mathrm{~g}$ \\
$\mathbf{T}_{\mathbf{9}}$ & $110.32 \mathrm{~b}$ & $111.57 \mathrm{a}$ & $47.01 \mathrm{~b}$ & $48.12 \mathrm{~b}$ \\
$\mathbf{T}_{\mathbf{1 0}}$ & $101.29 \mathrm{e}$ & $104.32 \mathrm{~d}$ & $44.35 \mathrm{~d}$ & $45.01 \mathrm{e}$ \\
$\mathbf{T}_{\mathbf{1 1}}$ & $111.45 \mathrm{a}$ & $112.22 \mathrm{a}$ & $48.36 \mathrm{a}$ & $49.01 \mathrm{a}$ \\
\hline
\end{tabular}

Means having the same letter(s) in each column are not significantly different at $5 \%$ level. ${ }^{*} \mathrm{~T}_{1}$; control (treatment of the farm), $\mathrm{T}_{2}$; chicken manure fertilizers, $\mathrm{T}_{3}$; chicken manure fertilizers + mycorrhizae, $\mathrm{T}_{4}$; chicken manure fertilizers + A. chroococcum, $\mathrm{T}_{5}$; chicken manure fertilizers + B. circulans, $\mathrm{T}_{6} ;$ c chicken manure fertilizers + mycorrhizae + A. chroococcum + B. circulans, $\mathrm{T}_{7}$; chicken manure tea, $\mathrm{T}_{8}$; chicken manure tea + microhiza, $\mathrm{T}_{9}$; chicken manure tea $+A$. chroococcum, $\mathrm{T}_{10}$; chicken manure tea $+B$. circulans and $\mathrm{T}_{11}$; chicken manure tea + mycorrhizae + A. chroococcum + B. circulans + mycorrhizae.

These results are parallel with Abd El-Hady et al. (2003) on Flame seedless grapevines, Abd El-Hamied (2007) on Thompson seedless grapevines and Sefan (2009) on King Ruby grapevines. Fayed (2010a) on Manfalouty pomegranate trees found that compost tea gave a significant increase in total chlorophyll and leaf area. A similar trend was observed by Fayed (2010b), who found that the compost tea significantly increased the vegetative parameters of the Roghini olive trees. Soil application of compost tea gave better effect on all vegetative characteristics and leaf total chlorophyll content of pear trees (Mohamed et al., 2010). Bio fertilization is beneficial in 
stimulating growth of pomes and stone fruits (Von-Bennewitz and Hlusek 2006). Kundu et al. (2011) showing that Azotobacter + vesicular-AM were effective and might be adopted to improve the vegetative growth on mango trees. Similar results of growth promotion with biofertilizers also reported by Dwivedi et al. (2012) in guava.

\section{Leaf Mineral Content}

It is evident from the data in table (5), that all treatments were significantly effective on mango N, P and K content in leaves. Application of $\mathrm{T}_{11}$ increased leaf nitrogen $(1.45 \%$ in the first season and $1.48 \%$ in the second season), followed by $\mathrm{T}_{9}$ in both seasons. However, there were insignificant differences between application $\mathrm{T}_{11}$ and $\mathrm{T}_{9}$ in leaf $\mathrm{P}$ and $\mathrm{K}$ content. While, $\mathrm{T}_{6}$ came after, in both seasons. In addition, $\mathrm{T}_{1}$ gave the lowest $\mathrm{N}$ content (1.01 and $1.04 \%$ in both seasons), $\mathrm{P}$ content $(0.110$ and $0.130 \%$ in the first and second season, respectively) and $\mathrm{K}$ content $(0.23$ and $0.40 \%$ in both seasons, respectively) in leaves.

Table (5). Effect of organic and bio-fertilizers on leaf nitrogen, phosphorus and potassium content of leaf mango trees during 2017 and 2018 seasons.

\begin{tabular}{|c|c|c|c|c|c|c|}
\hline \multirow[t]{2}{*}{${ }^{*}$ Treatments } & \multicolumn{2}{|c|}{$\begin{array}{l}\mathrm{N} \\
(\%)\end{array}$} & \multicolumn{2}{|c|}{$\begin{array}{l}\mathrm{P} \\
(\%)\end{array}$} & \multicolumn{2}{|c|}{$\begin{array}{l}\mathrm{K} \\
(\%)\end{array}$} \\
\hline & 2017 & 2018 & 2017 & 2018 & 2017 & 2018 \\
\hline$T_{1}$ & $1.01 \mathrm{k}$ & $1.04 \mathrm{k}$ & $0.110 \mathrm{i}$ & $0.130 \mathrm{i}$ & $0.23 \mathrm{~g}$ & $0.40 \mathrm{i}$ \\
\hline $\mathbf{T}_{2}$ & $1.04 \mathrm{j}$ & $1.10 \mathrm{j}$ & $0.133 \mathrm{hi}$ & $0.140 \mathrm{~h}$ & $0.40 \mathrm{f}$ & $0.50 \mathrm{~h}$ \\
\hline $\mathbf{T}_{3}$ & $1.10 \mathrm{~h}$ & $1.17 \mathrm{~h}$ & $0.140 \mathrm{fg}$ & $0.150 \mathrm{fgh}$ & $0.60 \mathrm{de}$ & $0.73 \mathrm{f}$ \\
\hline $\mathbf{T}_{4}$ & $1.31 \mathrm{~d}$ & $1.36 \mathrm{~d}$ & $0.163 \mathrm{~cd}$ & $0.160 \mathrm{~cd}$ & $1.12 b$ & $1.13 b c$ \\
\hline $\mathbf{T}_{5}$ & $1.18 \mathrm{f}$ & $1.28 \mathrm{f}$ & $0.153 \mathrm{ef}$ & $0.153 \mathrm{ef}$ & $0.90 \mathrm{c}$ & $1.07 \mathrm{~d}$ \\
\hline $\mathbf{T}_{6}$ & $1.38 \mathrm{c}$ & $1.40 \mathrm{c}$ & $0.160 b c$ & $0.170 b c$ & $1.13 b$ & $1.15 \mathrm{abc}$ \\
\hline $\mathbf{T}_{7}$ & $1.07 \mathrm{i}$ & $1.13 \mathrm{i}$ & $0.143 \mathrm{gh}$ & $0.143 \mathrm{gh}$ & $0.46 \mathrm{ef}$ & $0.63 \mathrm{~g}$ \\
\hline $\mathbf{T}_{8}$ & $1.13 \mathrm{~g}$ & $1.20 \mathrm{~g}$ & $0.146 \mathrm{fg}$ & $0.153 \mathrm{efg}$ & $0.73 \mathrm{~d}$ & $0.86 \mathrm{e}$ \\
\hline $\mathbf{T}_{9}$ & $1.40 \mathrm{~b}$ & $1.42 \mathrm{~b}$ & $0.170 \mathrm{ab}$ & $0.173 \mathrm{ab}$ & $1.30 \mathrm{a}$ & $1.18 \mathrm{ab}$ \\
\hline$T_{10}$ & $1.22 \mathrm{e}$ & $1.30 \mathrm{e}$ & $0.150 \mathrm{de}$ & $0.156 \mathrm{de}$ & $1.10 \mathrm{~b}$ & $1.12 \mathrm{~cd}$ \\
\hline$T_{11}$ & $1.45 \mathrm{a}$ & $1.48 \mathrm{a}$ & $0.173 \mathrm{a}$ & $0.180 \mathrm{a}$ & $1.19 \mathrm{ab}$ & $1.20 \mathrm{a}$ \\
\hline $\begin{array}{c}\text { \# Optimum } \\
\text { level }\end{array}$ & \multicolumn{2}{|c|}{$\mathrm{N}: 1.00-1.50$} & \multicolumn{2}{|c|}{ P: $0.13-0.18$} & \multicolumn{2}{|c|}{$\mathrm{K}: 0.30-1.20$} \\
\hline
\end{tabular}

Means having the same letter(s) in each column are not significantly different at $5 \%$ level. ${ }^{*} \mathrm{~T}_{1}$; control (treatment of the farm), $\mathrm{T}_{2}$; chicken manure fertilizers, $\mathrm{T}_{3}$; chicken manure fertilizers + mycorrhizae, $\mathrm{T}_{4}$; chicken manure fertilizers + A. chroococcum, $\mathrm{T}_{5}$; chicken manure fertilizers + B. circulans, $\mathrm{T}_{6}$; chicken manure fertilizers + mycorrhizae + A. chroococcum + B. circulans, $\mathrm{T}_{7}$; chicken manure tea, $\mathrm{T}_{8}$; chicken manure tea + microhiza, $\mathrm{T}_{9}$; chicken manure tea $+A$. chroococcum, $\mathrm{T}_{10}$; chicken manure tea $+B$. circulans and $\mathrm{T}_{11}$; chicken manure tea + mycorrhizae + A. chroococcum + B. circulans + mycorrhizae. \#Optimum level: was prepared utilizing from Jones et al. (1991).

Egyptian J. Desert Res., 69, No. 1, 39-66 (2019) 
These results could be attributed to the application of compost tea, which is efficient in enhancing the N, P and K absorption by roots. Generally, the important role of organic manures is due to the availability of nutrient elements through the reduction soil $\mathrm{pH}$ that increase the exchangeable capacity of nutrients mineral and reducing loss of them by leaching through drainage process. In addition, increased leaf nutrient mineral content by application of bio fertilizer and liquid fertilizers, may be due to the greater solubilization, that increase root surface to volume and permeation of hyphalpads beyond the explore zone of root hairs (Sau et al., 2017). Recently, biofertilizers have been developed to enhance nutrient uptake and satisfy requirements of several composts for fruit trees (Abd-Elmotty and Fawzy 2005).

These results are in agreement with El-Cobbia (1999), who found that applying either bio humus or cattle manure markedly increased leaf N, P and $\mathrm{K}$ content on Washington Navel orange trees. Also, Ebrahiem and Mohamed (2000) on Balady mandarin trees, Abd El-Hady et al. (2003) on Flame seedless grapevines. They found that organic and bio-fertilizers improved the percentages of N, P and K in the leaves. Furthermore, Abd-El-Hamied (2007) on Thompson seedless grapevines and Mostafa et al. (2009) on Washington Navel orange found that all treatments of compost tea applications gave a significant increase in leaf content of NPK\%. Soil application of compost tea gave better effect on macro and micro elements of pear trees (Mohamed et al., 2010). Also, Mostafa et al. (2011) reported that compost tea improvement of the nutritional status of grapes. Additionally, the great availability and release of $\mathrm{N}, \mathrm{P}$ and $\mathrm{K}$ due to the application of biofertilizers were announced by AbdRabou (2006) on avocados and mangos. Also, El-Naggar, (2004) showed that mycrohyza and Azotobacter were favorable in improving nutritional status of grapevines trees.

\section{Fruit Set and Fruit Drop}

Concerning the results in table (6), all treatments were significantly effective on mango fruit set and fruit drop in both seasons. $\mathrm{T}_{11}$ increased fruit set followed by $T_{9}$ in the first season. Moreover, there was insignificant difference between $T_{11}$ and $T_{9}$ in fruit set in the second season. Furthermore, $T_{11}$ gave the lowest fruit drop in both seasons comparing with $T_{1}, T_{2}$ and $T_{7}$, which gave the highest fruit drop. In the first season, $T_{1}$ and $T_{2}$ gave the highest fruit drop, followed by $T_{7}$. On the other hand, $T_{1}$ and $T_{7}$ gave the highest fruit drop in the second season, followed by $\mathrm{T}_{2}$.

The basis of the beneficial effect of compost tea on fruit set and decreased fruit drop is due to that compost tea has an improvement effect on the nutritional status of the plant as a result of its content (macro and micronutrients and in addition to the high value of useful bacteria, fungi and actinomycetes) in the solution.

Egyptian J. Desert Res., 69, No. 1, 39-66 (2019) 
Table (6). Effect of organic and biofertilizers on fruit set and fruit drop of mango trees during 2017 and 2018 seasons.

\begin{tabular}{ccccc}
\hline "Treatments & \multicolumn{2}{c}{$\begin{array}{c}\text { Fruit set } \\
\text { (\%) }\end{array}$} & \multicolumn{2}{c}{$\begin{array}{c}\text { Fruit drop } \\
\text { (\%) }\end{array}$} \\
\cline { 2 - 5 } & $\mathbf{2 0 1 7}$ & $\mathbf{2 0 1 8}$ & $\mathbf{2 0 1 7}$ & $\mathbf{2 0 1 8}$ \\
\hline $\mathbf{T}_{\mathbf{1}}$ & $2.75 \mathrm{f}$ & $2.84 \mathrm{~g}$ & $65.00 \mathrm{a}$ & $64.38 \mathrm{a}$ \\
$\mathbf{T}_{\mathbf{2}}$ & $2.87 \mathrm{ef}$ & $3.01 \mathrm{fg}$ & $64.55 \mathrm{a}$ & $63.04 \mathrm{~b}$ \\
$\mathbf{T}_{\mathbf{3}}$ & $3.27 \mathrm{de}$ & $3.59 \mathrm{e}$ & $63.48 \mathrm{c}$ & $62.54 \mathrm{c}$ \\
$\mathbf{T}_{\mathbf{4}}$ & $4.47 \mathrm{bc}$ & $4.68 \mathrm{bc}$ & $60.14 \mathrm{~g}$ & $58.62 \mathrm{~g}$ \\
$\mathbf{T}_{\mathbf{5}}$ & $4.29 \mathrm{c}$ & $4.16 \mathrm{~d}$ & $61.48 \mathrm{e}$ & $60.48 \mathrm{e}$ \\
$\mathbf{T}_{\mathbf{6}}$ & $4.52 \mathrm{bc}$ & $4.87 \mathrm{~b}$ & $56.77 \mathrm{~h}$ & $55.22 \mathrm{~h}$ \\
$\mathbf{T}_{\mathbf{7}}$ & $3.01 \mathrm{ef}$ & $3.31 \mathrm{ef}$ & $64.00 \mathrm{~b}$ & $64.32 \mathrm{a}$ \\
$\mathbf{T}_{\mathbf{8}}$ & $3.53 \mathrm{~d}$ & $3.60 \mathrm{e}$ & $62.87 \mathrm{~d}$ & $61.01 \mathrm{~d}$ \\
$\mathbf{T}_{\mathbf{9}}$ & $4.78 \mathrm{~b}$ & $5.00 \mathrm{ab}$ & $55.88 \mathrm{i}$ & $54.57 \mathrm{i}$ \\
$\mathbf{T}_{\mathbf{1 0}}$ & $4.22 \mathrm{c}$ & $4.49 \mathrm{~cd}$ & $60.98 \mathrm{f}$ & $59.78 \mathrm{f}$ \\
$\mathbf{T}_{\mathbf{1 1}}$ & $5.20 \mathrm{a}$ & $5.32 \mathrm{a}$ & $53.22 \mathrm{j}$ & $52.46 \mathrm{j}$ \\
\hline
\end{tabular}

Means having the same letter(s) in each column are not significantly different at $5 \%$ level. ${ }^{*} \mathrm{~T}_{1}$; control (treatment of the farm), $\mathrm{T}_{2}$; chicken manure fertilizers, $\mathrm{T}_{3}$; chicken manure fertilizers + mycorrhizae, $\mathrm{T}_{4}$; chicken manure fertilizers + A. chroococcum, $\mathrm{T}_{5}$; chicken manure fertilizers $+B$. circulans, $\mathrm{T}_{6}$; chicken manure fertilizers + mycorrhizae $+A$. chroococcum + B. circulans, $\mathrm{T}_{7}$; chicken manure tea, $\mathrm{T}_{8}$; chicken manure tea + microhiza, $\mathrm{T}_{9}$; chicken manure tea $+A$. chroococcum, $\mathrm{T}_{10}$; chicken manure tea $+B$. circulans and $\mathrm{T}_{11}$; chicken manure tea + mycorrhizae $+A$. chroococcum $+B$. circulans + mycorrhizae.

These results are in line with Yadav et al. (2007), who found that the organic fertilizers and bio fertilizers are enhancing the initial fruit setting of mango. Moustafa (2002) found that compost tea was the most efficient in enhancing tree fruiting of Washington navel orange trees, hence it increased fruit set percentage, reduced fruit drop. In addition, bio fertilization is beneficial in stimulating fruiting of pomes and stone fruits (Von-Bennewitz and Hlusek, 2006).

\section{Fruits Number and Total Yield}

Table (7) shows that all treatments were significantly effective on mango fruits number and total yield in both seasons. $\mathrm{T}_{11}$ increased fruits number in the second season and total yield in both seasons. While, there was none significant difference between $T_{11}$ and $T_{9}$ in fruits number, followed by $\mathrm{T}_{6}$ in the first season. On the other hand, $\mathrm{T}_{1}$ and $\mathrm{T}_{2}$ gave the lowest fruits number in the first season. While, $\mathrm{T}_{1}$ only gave the lowest fruits number in the second season. In addition, $T_{1}$ gave the lowest total yield in the first season and there was insignificant difference between $T_{1}$ and $T_{2}$ in total yield in the second season.

The increase in the total yield resulted from application of the chicken manure tea may be attributed to the presence of readily available form of

Egyptian J. Desert Res., 69, No. 1, 39-66 (2019) 
nutrient; i.e. ammonia and nitrate (Gross et al., 2007) and also to its property to enhance soil aggregation, soil aeration and water holding capacity, offering good environmental conditions for the root system. This better availability of soil nutrients and favorable soil condition resulted in healthy trees, giving higher yield. The lowest yield in control is due to the insufficient nitrogen supply for the plants that resulting in reduction of yield (Lawlor, 2002). It is obvious that, use of bio-fertilizers can improve productivity in a relatively short time with improving soil fertility as they release more amount of $\mathrm{N}, \mathrm{P}$ and $\mathrm{K}$ (Corpoica, 2007). In addition, biofertilizers are known to increase the nitrogen fixation and nutrient content of soil (Babita and Thakur, 2015), producing growth stimulants for plants, improving soil stability, providing biological control, biodegrading substances, recycling nutrients, promoting mycorrhiza symbiosis (Rivera-Cruz et al., 2008) that sequentially improve yield.

Table (7). Effect of organic and biofertilizers on fruits number and total yield of mango trees during 2017 and 2018 seasons

\begin{tabular}{ccccc}
\hline "Treatments & \multicolumn{2}{c}{$\begin{array}{c}\text { Fruits number/ } \\
\text { tree }\end{array}$} & \multicolumn{2}{c}{$\begin{array}{c}\text { Total yield } \\
\text { (kg/tree) }\end{array}$} \\
\cline { 2 - 5 } & $\mathbf{2 0 1 7}$ & $\mathbf{2 0 1 8}$ & $\mathbf{2 0 1 7}$ & $\mathbf{2 0 1 8}$ \\
\hline $\mathbf{T}_{\mathbf{1}}$ & $75.33 \mathrm{~h}$ & $77.09 \mathrm{j}$ & $18.35 \mathrm{k}$ & $20.10 \mathrm{k}$ \\
$\mathbf{T}_{\mathbf{2}}$ & $76.28 \mathrm{~h}$ & $79.195 \mathrm{j}$ & $20.28 \mathrm{j}$ & $22.30 \mathrm{j}$ \\
$\mathbf{T}_{\mathbf{3}}$ & $95.76 \mathrm{fg}$ & $103.54 \mathrm{~h}$ & $27.26 \mathrm{~h}$ & $31.77 \mathrm{~h}$ \\
$\mathbf{T}_{\mathbf{4}}$ & $120.64 \mathrm{c}$ & $124.66 \mathrm{~d}$ & $40.73 \mathrm{~d}$ & $42.88 \mathrm{~d}$ \\
$\mathbf{T}_{\mathbf{5}}$ & $103.21 \mathrm{e}$ & $117.93 \mathrm{f}$ & $32.19 \mathrm{f}$ & $38.12 \mathrm{f}$ \\
$\mathbf{T}_{\mathbf{6}}$ & $128.46 \mathrm{~b}$ & $127.19 \mathrm{c}$ & $44.43 \mathrm{c}$ & $45.24 \mathrm{c}$ \\
$\mathbf{T}_{\mathbf{7}}$ & $93.80 \mathrm{~g}$ & $94.73 \mathrm{i}$ & $26.03 \mathrm{i}$ & $28.15 \mathrm{i}$ \\
$\mathbf{T}_{\mathbf{8}}$ & $97.45 \mathrm{f}$ & $113.17 \mathrm{~g}$ & $29.47 \mathrm{~g}$ & $35.98 \mathrm{~g}$ \\
$\mathbf{T}_{\mathbf{9}}$ & $135.40 \mathrm{a}$ & $135.57 \mathrm{~b}$ & $47.56 \mathrm{~b}$ & $49.67 \mathrm{~b}$ \\
$\mathbf{T}_{\mathbf{1 0}}$ & $117.91 \mathrm{~d}$ & $120.64 \mathrm{e}$ & $37.78 \mathrm{e}$ & $40.00 \mathrm{e}$ \\
$\mathbf{T}_{\mathbf{1 1}}$ & $136.12 \mathrm{a}$ & $139.85 \mathrm{a}$ & $50.12 \mathrm{a}$ & $52.01 \mathrm{a}$ \\
\hline
\end{tabular}

Means having the same letter(s) in each column are not significantly different at $5 \%$ level. ${ }^{*} \mathrm{~T}_{1}$; control (treatment of the farm), $\mathrm{T}_{2}$; chicken manure fertilizers, $\mathrm{T}_{3}$; chicken manure fertilizers + mycorrhizae, $\mathrm{T}_{4}$; chicken manure fertilizers + A. chroococcum, $\mathrm{T}_{5}$; chicken manure fertilizers + B. circulans, $\mathrm{T}_{6}$; chicken manure fertilizers + mycorrhizae + A. chroococcum + B. circulans, $\mathrm{T}_{7}$; chicken manure tea, $\mathrm{T}_{8}$; chicken manure tea + microhiza, $\mathrm{T}_{9}$; chicken manure tea $+A$. chroococcum, $\mathrm{T}_{10}$; chicken manure tea $+B$. circulans and $\mathrm{T}_{11}$; chicken manure tea + mycorrhizae + A. chroococcum + B. circulans + mycorrhizae.

These results are in line with Moustafa (2002), who found that compost tea improved yield (fruits number and yield $\mathrm{kg} /$ tree) of Washington navel orange. Likewise, Mostafa et al. (2009) on Thompson seedless grapevines reported that the combination of compost tea and chicken manure extract gave a significant increasing the yield/vine. Also, El-Mansi (2007) and 
Abd El-Hamied (2007) indicated that the yield of Thompson seedless grapevines increased by using different types of compost as compared with that of control. Mostafa et al. (2009) on Washington Navel orange trees reported that compost tea increased the total yield. Also, Fayed (2010a) on Manfalouty pomegranate trees found that compost tea increased yield. Soil application of compost tea gave better effect on fruit yield of pear trees compared to control (Mohamed et al., 2010). Also, Mostafa et al. (2011) reported that compost tea produced the maximum yield of grapes. Biofertilizers are the most important for plant production and soil as they play an important role in improving fruit quality and yield of grapevines (Akl et al., 1997). Also, El-Naggar (2004) showed that mycorrhizae and Azotobacter were favorable in improving yield of grapevines. Aseri et al. (2008) found that the use of biofertilizers has given a significant improvement of fruits of pomegranate as well as enhancing the rhizosphere microbial activity and concentration of various nutrients. Kundu et al. (2011) showed that Azotobacter + vesicular-AM were effective and might be adopted to improve productivity of mango trees.

\section{Fruit Length, Fruit Diameter and Fruit Weight}

It is evident from the data in table (8) that fruit length, fruit diameter and fruit weight of mango trees were significantly affected by different treatments in both seasons. There was insignificant difference between $T_{11}$ and $T_{9}$ in fruit length and diameter, followed by $T_{6}$ in both seasons. In addition, $T_{11}$ has given the high value of fruit length (12.32 and $12.55 \mathrm{~cm}$ in both seasons) and fruit diameter ( 9.47 and $9.54 \mathrm{~cm}$ in the first and second seasons, respectively). Furthermore, $\mathrm{T}_{11}$ has given the highest fruit weight (368.22 and $371.89 \mathrm{~g}$ in both seasons), followed by $T_{9}$ in both seasons. On the other hand, $\mathrm{T}_{1}$ and $\mathrm{T}_{2}$ gave the lowest fruit length and diameter in both season. While, $T_{1}$ gave the lowest fruit weight in both seasons, followed by $\mathrm{T}_{2}$.

\section{Total Soluble Solid, Total Sugar, Total Acidity and Vitamin C}

Results presented in table (9) indicate that total TSS, total sugar, and vitamin $\mathrm{c}$ in Sukarry mango fruits were significantly increased and total acidity decreased by different treatments in the two seasons. However, $\mathrm{T}_{11}$ and $\mathrm{T}_{9}$ increased total sugar in the first season and $\mathrm{T}_{11}$ increased total sugar, followed by $T_{9}$ in the second season. Vitamin $\mathrm{c}$ increased with $\mathrm{T}_{11}$, followed by $\mathrm{T}_{9}$ in both seasons. In addition, $\mathrm{T}_{11}$ and $\mathrm{T}_{9}$ decreased total acidity $(0.26$ and $0.25 \%$ in both seasons, respectively), followed by $\mathrm{T}_{6}$. In both seasons TSS increased with $\mathrm{T}_{11}(19.24 \%$ in the first season and $19.55 \%$ in the second season), $\mathrm{T}_{9}\left(18.61\right.$ and $18.98 \%$ in both seasons). On the other hand, $\mathrm{T}_{1}$ gave the lowest total sugar, vitamin $\mathrm{c}$ and TSS and gave the highest total acidity in both seasons. 
Table (8). Effect of organic and biofertilizers on fruit length, fruit diameter and fruit weight of mango trees during 2017 and 2018 seasons

\begin{tabular}{ccccccc}
\hline "Treatments & \multicolumn{2}{c}{ Fruit length $\mathbf{( c m})$} & \multicolumn{2}{c}{ Fruit diameter $(\mathbf{c m})$} & \multicolumn{2}{c}{ Fruit weight $(\mathbf{g})$} \\
\cline { 2 - 7 } & $\mathbf{2 0 1 7}$ & $\mathbf{2 0 1 8}$ & $\mathbf{2 0 1 7}$ & $\mathbf{2 0 1 8}$ & $\mathbf{2 0 1 7}$ & $\mathbf{2 0 1 8}$ \\
\hline $\mathbf{T}_{\mathbf{1}}$ & $8.65 \mathrm{e}$ & $9.00 \mathrm{f}$ & $7.54 \mathrm{e}$ & $7.65 \mathrm{f}$ & $243.57 \mathrm{k}$ & $260.80 \mathrm{k}$ \\
$\mathbf{T}_{\mathbf{2}}$ & $9.00 \mathrm{e}$ & $9.55 \mathrm{e}$ & $7.86 \mathrm{e}$ & $7.98 \mathrm{ef}$ & $265.85 \mathrm{j}$ & $281.58 \mathrm{j}$ \\
$\mathbf{T}_{\mathbf{3}}$ & $10.00 \mathrm{~d}$ & $10.22 \mathrm{~d}$ & $8.13 \mathrm{de}$ & $8.20 \mathrm{de}$ & $284.68 \mathrm{~h}$ & $306.88 \mathrm{~h}$ \\
$\mathbf{T}_{\mathbf{4}}$ & $11.03 \mathrm{bc}$ & $11.02 \mathrm{c}$ & $8.98 \mathrm{abc}$ & $8.72 \mathrm{c}$ & $337.62 \mathrm{~d}$ & $343.99 \mathrm{~d}$ \\
$\mathbf{T}_{\mathbf{5}}$ & $10.18 \mathrm{~cd}$ & $10.88 \mathrm{c}$ & $8.65 \mathrm{bcd}$ & $8.54 \mathrm{~cd}$ & $311.92 \mathrm{f}$ & $323.26 \mathrm{f}$ \\
$\mathbf{T}_{\mathbf{6}}$ & $11.65 \mathrm{ab}$ & $11.92 \mathrm{~b}$ & $9.00 \mathrm{abc}$ & $9.45 \mathrm{a}$ & $345.87 \mathrm{c}$ & $355.68 \mathrm{c}$ \\
$\mathbf{T}_{\mathbf{7}}$ & $9.42 \mathrm{de}$ & $10.02 \mathrm{de}$ & $8.00 \mathrm{de}$ & $8.10 \mathrm{def}$ & $277.55 \mathrm{i}$ & $297.22 \mathrm{i}$ \\
$\mathbf{T}_{\mathbf{8}}$ & $10.22 \mathrm{~cd}$ & $10.51 \mathrm{~cd}$ & $8.27 \mathrm{cde}$ & $8.44 \mathrm{cde}$ & $302.47 \mathrm{~g}$ & $317.98 \mathrm{~g}$ \\
$\mathbf{T}_{\mathbf{9}}$ & $12.02 \mathrm{a}$ & $12.22 \mathrm{ab}$ & $9.26 \mathrm{ab}$ & $9.35 \mathrm{ab}$ & $351.25 \mathrm{~b}$ & $366.42 \mathrm{~b}$ \\
$\mathbf{T}_{\mathbf{1 0}}$ & $11.00 \mathrm{bc}$ & $11.03 \mathrm{c}$ & $8.26 \mathrm{cde}$ & $8.88 \mathrm{bc}$ & $320.45 \mathrm{e}$ & $331.55 \mathrm{e}$ \\
$\mathbf{T}_{\mathbf{1 1}}$ & $12.32 \mathrm{a}$ & $12.55 \mathrm{a}$ & $9.47 \mathrm{a}$ & $9.54 \mathrm{a}$ & $368.22 \mathrm{a}$ & $371.89 \mathrm{a}$ \\
\hline
\end{tabular}

Means having the same letter(s) in each column are not significantly different at $5 \%$ level. ${ }^{*} \mathrm{~T}_{1}$; control (treatment of the farm), $\mathrm{T}_{2}$; chicken manure fertilizers, $\mathrm{T}_{3}$; chicken manure fertilizers + mycorrhizae, $\mathrm{T}_{4}$; chicken manure fertilizers + A. chroococcum, $\mathrm{T}_{5}$; chicken manure fertilizers + B. circulans, $\mathrm{T}_{6}$; chicken manure fertilizers + mycorrhizae + A. chroococcum $+B$. circulans, $\mathrm{T}_{7}$; chicken manure tea, $\mathrm{T}_{8}$; chicken manure tea + microhiza, $\mathrm{T}_{9}$; chicken manure tea $+A$. chroococcum, $\mathrm{T}_{10}$; chicken manure tea $+B$. circulans and $\mathrm{T}_{11}$; chicken manure tea + mycorrhizae + A. chroococcum + B. circulans + mycorrhizae.

The increase of fruit physical and chemical parameters that occurred may be due to that chicken manure tea was effective in improving fruit qualities as it is enriched with mineral nutrients, vitamins, essential amino acids, growth promoting substances like IAA, GA and some beneficial organism (Natarajan, 2007). In addition, it may be due their role in nitrogen fixation, production of phyto-hormone like substances and the increased uptake of nutrients, particularly micronutrients, which are normally not available to the tree (Babita and Thakur, 2015).

The obtained results are in agreement with the findings of Abd ElHamied (2007) on Thompson seedless grapevines, who found that combination between compost tea and chicken manure extract has given the highest values in total sugars (\%) in berries. Also, Sefan (2009) on King Ruby grapevines, found that application of compost gave the highest values of total sugar in berries during both seasons. Fayed (2010a) on Manfalouty pomegranate trees found that compost tea gave a significant increase in total sugars in fruits in both seasons. Similarly, Mostafa et al. (2011) reported that compost tea improves quality of grapes. In addition, Dutta and Kundu (2012) found that bio-fertilizers are effective in fruit quality (TSS, total sugar and vitamin c) and decreased total acidity of mango and Devi et al. (2012) found the same results in Litchi. 
Table (9). Effect of organic and biofertilizers on total soluble solid (TSS), total sugar, total acidity and vitamin c content of mango trees during 2017 and 2018 seasons.

\begin{tabular}{|c|c|c|c|c|c|c|c|c|}
\hline \multirow[t]{2}{*}{ "Treatments } & \multicolumn{2}{|c|}{$\begin{array}{l}\text { Total sugar } \\
(\%)\end{array}$} & \multicolumn{2}{|c|}{$\begin{array}{c}\text { Vitamin C } \\
\text { (mg/100 g pulp) }\end{array}$} & \multicolumn{2}{|c|}{$\begin{array}{c}\text { Total acidity } \\
\text { (\%) }\end{array}$} & \multicolumn{2}{|c|}{$\begin{array}{l}\text { TSS } \\
(\%)\end{array}$} \\
\hline & 2017 & 2018 & 2017 & 2018 & 2017 & 2018 & 2017 & 2018 \\
\hline $\mathbf{T}_{1}$ & $9.45 \mathrm{f}$ & $9.47 \mathrm{i}$ & $22.61 \mathrm{i}$ & $23.00 \mathrm{i}$ & $0.35 a$ & $0.34 \mathrm{a}$ & $11.23 \mathrm{~g}$ & $11.76 \mathrm{~h}$ \\
\hline $\mathbf{T}_{2}$ & $10.11 \mathrm{f}$ & $10.53 \mathrm{~h}$ & $23.51 \mathrm{~h}$ & $24.66 \mathrm{~h}$ & $0.34 \mathrm{~b}$ & $0.32 b$ & $12.01 \mathrm{f}$ & $12.48 \mathrm{gh}$ \\
\hline $\mathbf{T}_{3}$ & $11.43 \mathrm{e}$ & $12.26 \mathrm{~g}$ & $25.00 \mathrm{~g}$ & $25.72 \mathrm{~g}$ & $0.31 \mathrm{~d}$ & $0.30 \mathrm{c}$ & $13.77 \mathrm{e}$ & $14.32 \mathrm{f}$ \\
\hline $\mathbf{T}_{4}$ & $14.77 b c$ & $15.36 \mathrm{~cd}$ & $29.46 \mathrm{~d}$ & $30.53 \mathrm{~d}$ & $0.28 \mathrm{f}$ & $0.27 \mathrm{fg}$ & $16.97 \mathrm{~b}$ & $17.56 \mathrm{~b}$ \\
\hline $\mathbf{T}_{5}$ & $13.20 \mathrm{~d}$ & $14.24 \mathrm{e}$ & $26.72 \mathrm{e}$ & $27.37 f$ & $0.29 \mathrm{e}$ & $0.28 \mathrm{e}$ & $15.16 \mathrm{~d}$ & $16.00 \mathrm{~d}$ \\
\hline $\mathbf{T}_{6}$ & $15.43 b$ & $16.05 b c$ & $31.23 \mathrm{c}$ & $32.72 \mathrm{c}$ & $0.27 \mathrm{~g}$ & $0.26 \mathrm{~g}$ & $17.22 b$ & $18.01 \mathrm{~b}$ \\
\hline $\mathbf{T}_{7}$ & $11.66 \mathrm{e}$ & $11.23 \mathrm{~h}$ & $24.32 \mathrm{~g}$ & $25.01 \mathrm{~h}$ & $0.32 \mathrm{c}$ & $0.32 b$ & $12.29 \mathrm{f}$ & $13.22 \mathrm{~g}$ \\
\hline $\mathbf{T}_{8}$ & $13.00 \mathrm{~d}$ & $13.19 \mathrm{f}$ & $25.83 \mathrm{f}$ & $27.29 \mathrm{f}$ & $0.29 \mathrm{e}$ & $0.29 \mathrm{~d}$ & $15.22 \mathrm{~d}$ & $15.20 \mathrm{e}$ \\
\hline $\mathbf{T}_{9}$ & $16.54 \mathrm{a}$ & $16.72 b$ & $32.43 b$ & $33.82 \mathrm{~b}$ & $0.26 \mathrm{~h}$ & $0.25 \mathrm{~h}$ & $18.61 \mathrm{a}$ & $18.98 \mathrm{a}$ \\
\hline$T_{10}$ & $14.12 \mathrm{c}$ & $14.85 \mathrm{de}$ & $27.18 \mathrm{e}$ & $28.21 \mathrm{e}$ & $0.28 \mathrm{f}$ & $0.27 \mathrm{ef}$ & $16.01 \mathrm{c}$ & $16.77 \mathrm{c}$ \\
\hline$T_{11}$ & $17.01 \mathrm{a}$ & $17.88 \mathrm{a}$ & $34.01 \mathrm{a}$ & $34.58 \mathrm{a}$ & $0.26 \mathrm{~h}$ & $0.25 \mathrm{~h}$ & $19.24 \mathrm{a}$ & $19.55 \mathrm{a}$ \\
\hline & hizae, 1 & $\begin{array}{l}\text { letter( } \\
\text { he farm } \\
\text { ken ma } \\
\text { ken mar }\end{array}$ & 1 & e not & icant & $\begin{array}{l}\text { ferent } \\
\text { ken } \\
\text { cken } n\end{array}$ & $\begin{array}{l}\text { olevel. } \\
\text { e fertili } \\
\text { e fertili } \\
\text { circul } \\
\text { re tea }\end{array}$ & \\
\hline
\end{tabular}

\section{Microbiological Measurements}

The total microbial counts $(\mathrm{x} 106 \mathrm{cfu} / \mathrm{g}$ dry soil) in soil were determined at both seasons, respectively. The most probable number (MPN) (x10 $10^{4}$ fu /g dry soil) used to measure Azotobacter density on modified Ashby's media at the same periods in both seasons. Counts of phosphate dissolving bacterial counts $\left(\times 10^{3} \mathrm{cfu} / \mathrm{g}\right.$ dry soil $)$ were determined. The colonization percentage of AMF and spores number after each season were also determined.

\subsection{Total microbial counts}

Initial total microbial counts before cultivation were $82 \times 10^{6} \mathrm{cfu} / \mathrm{g}$ dry soil (Table 10). Generally, the counts at the second season were higher than those of the first season and all the treatments exceeded the control. Total microbial counts differed from chicken manure and maure tea and bio fertilization treatments, which might be due to the simulative effect of added biofertilizers on microbial community in mango tree rhizosphere that leads to increasing in total microbial counts. The enhancement effect of microbial activity is a good parameter for many soil improvement indicators. For example $A$. chroococcum induces growth promoting substances, biological nitrogen fixation, organic acids production and other enzymatic activities,

Egyptian J. Desert Res., 69, No. 1, 39-66 (2019) 
which enhances plant growth and proliferates lateral roots and root hairs, which increases nutrient absorbing surface (Abd El-Ghany et al., 2010).

The highest counts were associated with the chicken manure tea application and mixed bio fertilization treatment $\left(T_{11}\right)$ being 216 and $259 \times 10^{6}$ cfu/g dry soil at the first and second seasons of soil mango tree, respectively. These results are compatible with those obtained by Ashrafuzzaman et al. (2009), who reported that, inoculation with the plant growth promoting rhizobacteria like Azotobacter, had stimulation effect on the population of rhizosphere microorganisms and increased their numbers by more than $50 \%$ at the end of the experiment comparing with the number recorded before planting.

\subsection{Azotobacter densities}

Represented data in table (10) recorded improvement in Azotobacter densitiy by different treatments as compared with the control. Inoculation with different biofertilizers A. chroococcum, B. circulans and G. macrocarbium (individually or mixed) with chicken manure or manure tea had stimulating effect on Azotobacter densities in rhizosphere.

Interaction of A. chroococcum, B. circulans and G. macrocarbium in mixed treatment $\left(T_{11}\right)$ recorded the highest increase than $T_{1}$ to be 66.3 and $68.6 \%$ of increase than the first and second growth seasons of mango, respectively. The promoting effect due to application of $A$. chroococcum not only is due to the nitrogen fixation but also due to the production of plant growth promoting substances, production of amino acids, organic acids, vitamins and antimicrobial substances as well, which increase soil fertility, microbial community and plant growth (Revillas et al., 2005).

All biofertilization treatments improved the microbial activity in the rhizosphere soil and recorded significant increases, compared to the uninoculated treatment. These increases may be due to production of phytohormones; such as indolacetic acid, gibberellic acid, cytokinins and ethylene (Glick, 1995), a symbiotic $\mathrm{N}_{2}$ fixation (Dobbelaera et al., 2003), solubilization of mineral phosphates and other nutrients (De Freitas et al., 1997).

\subsection{Bacillus counts}

The initial Bacillus counts in study area were $18 \times 10^{3} \mathrm{cfu} / \mathrm{g}$ dry soil. Data recorded in table (10) prove a marked increase in Bacillus counts in the first and second seasons on mango tree. The counts under $\mathrm{T}_{11}$ produced the highest Bacillus counts being $54 \times 10^{3}$ and $59 \times 10^{3} \mathrm{cfu} / \mathrm{g}$ dry soil at the first and second seasons, respectively. The highest increase in Bacillus counts were obtained by using the $T_{11}$, followed by $T_{10}$ and $T_{6}$ application. The promoting effect due to the production of plant growth promoting substances as well, which increase soil fertility, microbial communities and plant growth (Yadav et al., 2007). These results are in agreement with those obtained by Ashrafuzzaman et. al. (2009), who reported that, inoculation with the plant 
growth promoting rhizobacteria (Azotobacter, Azospirillum, Bacillus megatheriu and Rhizobium) had stimulation effect on the population of rhizosphere microorganisms by increasing their numbers by more than $50 \%$.

Table (10). Effect of organic and biofertilizers on microbial determination in mango tree rhizosphere during 2017 and 2018 seasons.

\begin{tabular}{|c|c|c|c|c|c|c|}
\hline \multirow[t]{2}{*}{ "Treatments } & \multicolumn{2}{|c|}{$\begin{array}{c}\text { Total microbial } \\
\text { counts } \\
\left(\times 10^{6} \mathrm{cfu} / \mathrm{g} \text { dry }\right. \\
\text { soil) }\end{array}$} & \multicolumn{2}{|c|}{$\begin{array}{c}\text { Azotobacter } \\
\text { densities } \\
\left(\mathbf{x 1 0}^{4} \mathrm{cfu} / \mathrm{g} \text { dry }\right. \\
\text { soil) }\end{array}$} & \multicolumn{2}{|c|}{$\begin{array}{c}\text { Bacillus count } \\
\left(\times 10^{3} \mathrm{cfu} / \mathrm{g} \text { dry }\right. \\
\text { soil })\end{array}$} \\
\hline & 2017 & 2018 & 2017 & 2018 & 2017 & 2018 \\
\hline $\mathbf{T}_{1}$ & $115 j$ & $136 \mathrm{i}$ & $83 \mathrm{i}$ & $86 \mathrm{~h}$ & $27 \mathrm{i}$ & $34 \mathrm{f}$ \\
\hline $\mathbf{T}_{2}$ & $121 \mathrm{i}$ & $140 \mathrm{~h}$ & $104 \mathrm{~h}$ & $108 \mathrm{~g}$ & $29 \mathrm{~h}$ & $37 \mathrm{e}$ \\
\hline $\mathbf{T}_{3}$ & $165 \mathrm{~g}$ & $201 \mathrm{e}$ & $106 \mathrm{~h}$ & $111 \mathrm{f}$ & $36 \mathrm{ef}$ & $41 \mathrm{~d}$ \\
\hline $\mathbf{T}_{4}$ & $192 \mathrm{c}$ & $232 \mathrm{c}$ & $122 d$ & $131 \mathrm{c}$ & $34 \mathrm{~g}$ & $39 \mathrm{de}$ \\
\hline$T_{5}$ & $173 \mathrm{e}$ & $202 \mathrm{e}$ & $117 \mathrm{e}$ & $119 \mathrm{e}$ & $44 \mathrm{~d}$ & $47 \mathrm{c}$ \\
\hline $\mathbf{T}_{6}$ & $194 c$ & $234 \mathrm{c}$ & $127 \mathrm{c}$ & $133 b c$ & $47 \mathrm{c}$ & $54 \mathrm{~b}$ \\
\hline $\mathbf{T}_{7}$ & $158 \mathrm{~h}$ & $191 \mathrm{~g}$ & $109 \mathrm{~g}$ & $113 \mathrm{f}$ & $31 \mathrm{~g}$ & $37 \mathrm{e}$ \\
\hline $\mathbf{T}_{8}$ & $169 \mathrm{f}$ & $198 \mathrm{f}$ & $113 \mathrm{f}$ & $118 \mathrm{e}$ & $37 \mathrm{e}$ & $45 c$ \\
\hline $\mathbf{T}_{9}$ & $203 b$ & $246 b$ & $131 \mathrm{~b}$ & $136 b$ & $35 f$ & $39 \mathrm{de}$ \\
\hline $\mathbf{T}_{10}$ & $177 d$ & $208 d$ & $118 \mathrm{e}$ & $125 \mathrm{~d}$ & $51 \mathrm{~b}$ & $55 \mathrm{~b}$ \\
\hline$T_{11}$ & $216 a$ & $260 a$ & $138 \mathrm{a}$ & $145 \mathrm{a}$ & $54 \mathrm{a}$ & $59 a$ \\
\hline
\end{tabular}

Means having the same letter(s) in each column are not significantly different at $5 \%$ level. ${ }^{*} \mathrm{~T}_{1}$; control (treatment of the farm), $\mathrm{T}_{2}$; chicken manure fertilizers, $\mathrm{T}_{3}$; chicken manure fertilizers + mycorrhizae, $\mathrm{T}_{4}$; chicken manure fertilizers + A. chroococcum, $\mathrm{T}_{5}$; chicken manure fertilizers $+B$. circulans, $\mathrm{T}_{6}$; chicken manure fertilizers + mycorrhizae $+A$. chroococcum $+B$. circulans, $\mathrm{T}_{7}$; chicken manure tea, $\mathrm{T}_{8}$; chicken manure tea + microhiza, $\mathrm{T}_{9}$; chicken manure tea $+A$. chroococcum, $\mathrm{T}_{10}$; chicken manure tea $+B$. circulans and $\mathrm{T}_{11}$; chicken manure tea + mycorrhizae $+A$. chroococcum $+B$. circulans + mycorrhizae.

\subsection{Mycorrhizal root colonization}

As shown in table (11), inoculated plants were significantly colonized compared to uninoculated plants. The root colonization of mango tree was affected by microbial inoculation. The percent of root colonization was higher in the treatments inoculated with VAM compared to non-inoculated plants.

Egyptian J. Desert Res., 69, No. 1, 39-66 (2019) 
Table (11). Effect of organic and bio fertilizers on Mycorrhizal colonization $\%$ and spores/g in mango tree rhizosphere during 2017 and 2018 seasons.

\begin{tabular}{ccccc}
\hline \multirow{2}{*}{ Treatments } & \multicolumn{2}{c}{$\begin{array}{c}\text { Mycorrhizal } \\
\text { (spores/g soil) }\end{array}$} & \multicolumn{2}{c}{$\begin{array}{c}\text { Mycorrhizal } \\
\text { infection (\%) }\end{array}$} \\
\cline { 2 - 5 } & $\mathbf{2 0 1 7}$ & $\mathbf{2 0 1 8}$ & $\mathbf{2 0 1 7}$ & $\mathbf{2 0 1 8}$ \\
\hline $\mathbf{T}_{\mathbf{1}}$ & $10.00 \mathrm{~h}$ & $10.60 \mathrm{~h}$ & $9.10 \mathrm{j}$ & $9.5 \mathrm{e}$ \\
$\mathbf{T}_{\mathbf{2}}$ & $11.70 \mathrm{~g}$ & $12.30 \mathrm{~g}$ & $10.30 \mathrm{i}$ & $10.6 \mathrm{e}$ \\
$\mathbf{T}_{\mathbf{3}}$ & $14.10 \mathrm{f}$ & $14.90 \mathrm{f}$ & $33.00 \mathrm{f}$ & $34 \mathrm{bcd}$ \\
$\mathbf{T}_{\mathbf{4}}$ & $14.90 \mathrm{de}$ & $17.10 \mathrm{de}$ & $42.00 \mathrm{~cd}$ & $47 \mathrm{ab}$ \\
$\mathbf{T}_{\mathbf{5}}$ & $15.80 \mathrm{bc}$ & $17.80 \mathrm{~d}$ & $39.00 \mathrm{e}$ & $45 \mathrm{bc}$ \\
$\mathbf{T}_{\mathbf{6}}$ & $15.90 \mathrm{~b}$ & $18.40 \mathrm{~b}$ & $43.20 \mathrm{c}$ & $47.3 \mathrm{ab}$ \\
$\mathbf{T}_{7}$ & $12.00 \mathrm{~g}$ & $12.20 \mathrm{~g}$ & $19.80 \mathrm{~h}$ & $26.7 \mathrm{~d}$ \\
$\mathbf{T}_{\mathbf{8}}$ & $14.50 \mathrm{ef}$ & $14.40 \mathrm{ef}$ & $30.10 \mathrm{~g}$ & $30.3 \mathrm{~cd}$ \\
$\mathbf{T}_{\mathbf{9}}$ & $15.20 \mathrm{~cd}$ & $17.90 \mathrm{c}$ & $47.00 \mathrm{~b}$ & $47.7 \mathrm{ab}$ \\
$\mathbf{T}_{\mathbf{1 0}}$ & $16.70 \mathrm{a}$ & $19.30 \mathrm{a}$ & $41.20 \mathrm{~d}$ & $46.3 \mathrm{ab}$ \\
$\mathbf{T}_{\mathbf{1 1}}$ & $17.30 \mathrm{a}$ & $19.70 \mathrm{a}$ & $49.30 \mathrm{a}$ & $49.7 \mathrm{a}$ \\
\hline
\end{tabular}

Means having the same letter(s) in each column are not significantly different at $5 \%$ level. ${ }^{*} \mathrm{~T}_{1}$; control (treatment of the farm), $\mathrm{T}_{2}$; chicken manure fertilizers, $\mathrm{T}_{3}$; chicken manure fertilizers + mycorrhizae, $\mathrm{T}_{4}$; chicken manure fertilizers + A. chroococcum, $\mathrm{T}_{5}$; chicken manure fertilizers + B. circulans, $\mathrm{T}_{6}$; chicken manure fertilizers + mycorrhizae + A. chroococcum + B. circulans, $\mathrm{T}_{7}$; chicken manure tea, $\mathrm{T}_{8}$; chicken manure tea + microhiza, $\mathrm{T}_{9}$; chicken manure tea $+A$. chroococcum, $\mathrm{T}_{10}$; chicken manure tea $+B$. circulans and $\mathrm{T}_{11}$; chicken manure tea + mycorrhizae + A. chroococcum + B. circulans + mycorrhizae.

It is noticed that adding Azotobacter and Bacillus to AM in all mixed treatments gave higher colonization \% in rhizosphere regions to control treatment. Mycorrhizal colorization fluctuated from 9 to $49 \%$ and from 9.5 to $50 \%$ at the first and second seasons, respectively from $T_{1}$ to $T_{11}$. In this study, mycorrhizal spores/g fluctuated from 10 in control treatment to $17.3 \mathrm{spores} / \mathrm{g}$ at the first season and 10.6 spores $/ g$ in $T_{1}$ to 19.70 spores $/ g$ in $T_{11}$ in the second season. Moreover, the positive effect of mixed inoculation on the increase of root colonization \% and number of AM spores was recorded by Bahadori et al. (2013).

\subsection{Some soil chemical properties}

Presented data in table (12) show that mineral contents in soil (N, P and $\mathrm{K}$ ) at the two seasons and organic matter either chicken manure or chicken manure tea using four bio-fertilization treatments, indicated that mineral contents in soil were significantly affected in all treatments. Bio-fertilization treatments increased NPK content in soil, $T_{11}$ was considered as the best, followed by $\mathrm{T}_{9}$ and $\mathrm{T}_{6}$ while, $\mathrm{T}_{1}$ recorded the least value of NPK contents in soil. $\mathrm{T}_{11}$ gave the highest concentrations being $0.047,0.182$ and $0.082 \%$ for $\mathrm{N}, \mathrm{P}$ and $\mathrm{K}$ at the second season, respectively. 
The $\mathrm{pH}$ values range of soil sample showed slight difference between treatments. $\mathrm{pH}$ for soil of mango tree at the first and second seasons ranged between 7.54 to 7.48 compared to initial $\mathrm{pH}$ (7.90). Also, electrical conductivity differed from season to other and ranged between 2.67 to 1.50 $\mathrm{ds} / \mathrm{ml}$. In addition, $\mathrm{T}_{11}$ and $\mathrm{T}_{9}$ decreased $\mathrm{EC}$ (electrical conductivity) and $\mathrm{pH}$ in both seasons.

Table (12). Effect of organic and biofertilizers on some soil chemical properties in soil mango rhizosphere.

\begin{tabular}{|c|c|c|c|c|c|c|c|c|c|c|}
\hline \multirow[t]{2}{*}{ "Treatments } & \multicolumn{2}{|c|}{ N (\%) } & \multicolumn{2}{|c|}{$P(\%)$} & \multicolumn{2}{|c|}{ K (\%) } & \multicolumn{2}{|c|}{ pH } & \multicolumn{2}{|c|}{ EC $(\mathrm{dS} / \mathrm{ml})$} \\
\hline & 2017 & 2018 & 2017 & 2018 & 2017 & 2018 & 2017 & 2018 & 2017 & 2018 \\
\hline$T_{1}$ & $0.026 \mathrm{j}$ & $0.028 \mathrm{i}$ & $0.0090 \mathrm{~g}$ & $0.011 \mathrm{~g}$ & $0.052 \mathrm{~h}$ & $0.055 \mathrm{i}$ & $7.90 \mathrm{a}$ & $7.92 \mathrm{a}$ & $2.67 \mathrm{a}$ & $2.57 \mathrm{a}$ \\
\hline $\mathbf{T}_{2}$ & $0.029 \mathrm{i}$ & $0.032 \mathrm{~h}$ & $0.0130 \mathrm{f}$ & $0.013 \mathrm{f}$ & $0.060 \mathrm{~g}$ & $0.063 \mathrm{~h}$ & $7.88 \mathrm{~b}$ & $7.88 \mathrm{~b}$ & $2.36 \mathrm{~b}$ & $2.35 b$ \\
\hline $\mathbf{T}_{3}$ & $0.033 \mathrm{~h}$ & $0.035 \mathrm{~g}$ & $0.0140 \mathrm{e}$ & $0.014 \mathrm{e}$ & $0.067 \mathrm{f}$ & $0.069 \mathrm{f}$ & $7.86 \mathrm{c}$ & $7.85 \mathrm{c}$ & $2.17 \mathrm{c}$ & $2.13 \mathrm{c}$ \\
\hline $\mathbf{T}_{4}$ & $0.037 \mathrm{e}$ & $0.039 \mathrm{~d}$ & $0.0142 \mathrm{~d}$ & $0.016 \mathrm{c}$ & $0.074 \mathrm{~cd}$ & $0.076 \mathrm{~d}$ & $7.84 \mathrm{~d}$ & $7.80 \mathrm{~d}$ & $2.06 \mathrm{~d}$ & $1.96 \mathrm{~d}$ \\
\hline$T_{5}$ & $0.034 \mathrm{~g}$ & $0.037 \mathrm{f}$ & $0.0140 \mathrm{e}$ & $0.015 \mathrm{~d}$ & $0.072 \mathrm{e}$ & $0.075 \mathrm{e}$ & $7.81 \mathrm{e}$ & $7.75 \mathrm{e}$ & $1.90 \mathrm{e}$ & $1.86 \mathrm{e}$ \\
\hline$T_{6}$ & $0.041 \mathrm{c}$ & $0.045 \mathrm{~b}$ & $0.0146 \mathrm{c}$ & $0.017 \mathrm{~b}$ & $0.074 \mathrm{c}$ & $0.077 \mathrm{~d}$ & $7.78 \mathrm{f}$ & $7.71 \mathrm{f}$ & $1.82 \mathrm{f}$ & $1.80 \mathrm{f}$ \\
\hline $\mathbf{T}_{7}$ & $0.033 \mathrm{~h}$ & $0.036 \mathrm{~g}$ & $0.0140 \mathrm{e}$ & $0.015 \mathrm{~d}$ & $0.061 \mathrm{~g}$ & $0.064 \mathrm{~g}$ & $7.76 \mathrm{~g}$ & $7.68 \mathrm{~g}$ & $1.71 \mathrm{~g}$ & $1.67 \mathrm{~g}$ \\
\hline$T_{8}$ & $0.036 \mathrm{f}$ & $0.038 \mathrm{e}$ & $0.0130 \mathrm{f}$ & $0.015 d$ & $0.067 \mathrm{f}$ & $0.070 \mathrm{f}$ & $7.71 \mathrm{~h}$ & $7.64 \mathrm{~h}$ & $1.64 \mathrm{~h}$ & $1.60 \mathrm{~h}$ \\
\hline $\mathbf{T}_{9}$ & $0.042 b$ & $0.045 b$ & $0.0150 \mathrm{~b}$ & $0.017 \mathrm{~b}$ & $0.076 \mathrm{~b}$ & $0.080 \mathrm{~b}$ & $7.62 \mathrm{j}$ & $7.57 \mathrm{j}$ & $1.57 \mathrm{j}$ & $1.54 \mathrm{j}$ \\
\hline$T_{10}$ & $0.039 \mathrm{~d}$ & $0.042 \mathrm{c}$ & $0.0146 \mathrm{c}$ & $0.016 \mathrm{c}$ & $0.073 \mathrm{~d}$ & $0.078 \mathrm{c}$ & $7.68 \mathrm{i}$ & $7.61 \mathrm{i}$ & $1.60 \mathrm{i}$ & $1.58 \mathrm{i}$ \\
\hline$T_{11}$ & $0.043 \mathrm{a}$ & $0.047 \mathrm{a}$ & $0.0160 \mathrm{a}$ & $0.018 \mathrm{a}$ & $0.078 \mathrm{a}$ & $0.082 \mathrm{a}$ & $7.54 \mathrm{k}$ & $7.48 \mathrm{k}$ & $1.54 \mathrm{k}$ & $1.50 \mathrm{k}$ \\
\hline
\end{tabular}

Means having the same letter(s) in each column are not significantly different at $5 \%$ level. ${ }^{*} \mathrm{~T}_{1}$; control (treatment of the farm), $\mathrm{T}_{2}$; chicken manure fertilizers, $\mathrm{T}_{3}$; chicken manure fertilizers + mycorrhizae, $\mathrm{T}_{4}$; chicken manure fertilizers $+A$. chroococcum, $\mathrm{T}_{5}$; chicken manure fertilizers + B. circulans, $\mathrm{T}_{6}$; chicken manure fertilizers + mycorrhizae + A. chroococcum + B. circulans, $\mathrm{T}_{7}$; chicken manure tea, $\mathrm{T}_{8}$; chicken manure tea + microhiza, $\mathrm{T}_{9}$; chicken manure tea $+A$. chroococcum, $\mathrm{T}_{10}$; chicken manure tea $+B$. circulans and $\mathrm{T}_{11}$; chicken manure tea + mycorrhizae $+A$. chroococcum + B. circulans + mycorrhizae.

Many authors reported the role of organic matter and bio fertilization in improving some soil chemical properties. Zahir et al. (2004) opined that microorganisms are important component of soil environment and their large number is indicative for better soil health, which improves more nutrient availability from source to sink. Thus, utilization of organic fertilizer could be better contrivance for improving biological attributes of soil, which in turn may increase productivity and quality (Allen et al., 2002) of different fruit crops. Application of bio-fertilizers substantially increased the soil microbial population, which improve the soil health, thereby the growth and productivity of the crop. Similar result was obtained by Dutta and Kundu (2012) in mango. From the study, it is confirmed that biofertilizers and liquid organic product (Panchagavya) is an efficient and sustainable alternative to standard NPK fertilization as they revealed a positive influence on vegetative growth and yielding of fruits with desired quality in mango production. In respect of soil heath condition, the biofertilizer and panchagavya application

Egyptian J. Desert Res., 69, No. 1, 39-66 (2019) 
make it more fertile in a sustainable manner for getting prolonged benefit from such treated land.

\section{CONCLUSION}

Considering the previous results, it seems pertinent to indicate that application of chicken manure tea $+A$. chroococcum $+B$. circulans + microhiza enhanced the growth, productivity and quality of mango tree. Therefore, there is a good potential for further optimizing this soil amendment. Also, an economic analysis of the costs and benefits of the high performing organic treatments would be valuable. Also, minimizing the cost of production and in turn increased the income.

\section{REFERENCES}

A.O.A.C. (1985). In "Official Methods of Analysis". Association of Official Agricultural Chemists, 14 ${ }^{\text {th }}$ Ed.: Benjamin Franklin Station Washington, DC, USA, p. 490-510.

Abd El-Ghany, B.F., A.M.A. Rhawhia, A.T. El-Rahmany and M.M. El-Shazly (2010). Effect of some soil microorganisms on soil properties and wheat production under North Sinai conditions. J. App. Sci. Res., 4 (5): 559-579.

Abd El-Hady, A.M., M.A. Aly and M.M.El-Mongy (2003). Effect of some soil conditioners on counteracting the adverse effects of salinity on growth and fruiting of Flame seedless vines. Minia J. Agric. Res. Develop., 23 (4): 699-726.

Abd El-Hamied, S.Y. (2007). Effect of some natural organic nutrients on Thompson seedless grapevines. Ph.D. Thesis, Fac. of Agric., Mansoura Univ., Egypt.

Abd-Elmotty, E.Z. and M.I.F. Fawzy (2005). Response of Zebda and Langra mango trees to some biofertilization treatments. J. Agric. Sci. Mansoura Univ., 30 (6): 3331-3341.

Abd-Rabou, F.A. (2006). Effect of microbien, phosphorene and effective micro-organisms (EM) as bio-stimulants on growth of avocado and mango seedlings. Egyptian Journal of Applied Sciences, 21: 673-693.

Al-Erwy, A.S., A. Al-Toukhy, S.O. Bafeel (2016). Effect of chemical, organic and biofertilizers on photosynthetic pigments, carbohydrates and minerals of wheat (Triticum aestivum L.) irrigated with sea water. Int. J. Adv. Res. Biol. Sci., 3: 296-310.

Akl, A.M., F.F. Ahmed, F.M. El-Morsy and M.A. Ragab (1997). The effect of soil and foliar application of nitrogen, phosphorus and potassium on some vegetative and fruiting characteristics in White Banaty 
Seedless grapevines. II-Bud behavior, yield and fruit quality. Minia First Conference for Horticultural Crops, p. 453-476.

Allen, M.F., D.A. Jasper and J.C. Zak (2002). Microorganisms. Chapter 14, In: "Handbook of Ecological Restoration", Volume 1 "Principle of Restoration" (Devi, A.J. and M. Perrow eds.), Cambridge University Press, p. 257-78.

Aseri, G.K., N. Jain, J. Panwar, A.V. Rao and P.R. Meghwal (2008). Biofertilizers improve plant growth, fruit yield, nutrition, metabolism and rhizosphere enzyme activities of pomegranate (Punica granatum L.) in Indian Thar Desert. Scientia Horticultural, 117: 130-135.

Ashrafuzzaman, M., F.A. Hossen, M.R. Ismail, M.A. Hoque, M.Z. Islam, S.M. Shahidullah and S. Meon (2009). Efficiency of plant growthpromoting rhizobacteria (PGPR) for the enhancement of rice growth. African Journal of Biotechnology, 8 (7): 1247-1252.

Atlas, R.M. (2004). In: "Handbook of Microbiological Media". $3^{\text {rd }}$ Edition. Washington DC: CRC press, $1483 \mathrm{pp}$.

Babita, N.A. and M. Thakur (2015). Organic farming: a holistic approach towards sustainable fruit production. Euro. J. Pharm. Med. Res., 2: 108-115.

Bahadori, F., E.S. Ashorabadi, M. Mirzam, M. Matinizade and V. Abdosi (2013). Improved growth, essential oil yield and quality in Thymus daenensis Celak on mycorrhizal and plant growth promoting rhizobacteria inoculation. Int. J. Agron. Prod., 4 (12): 3384-3391.

Barea, J.M., J. Palenzuela, P. Cornejo, I. Sánchez-Castro, C. NavarroFernández, A. Lopéz-García, B. Estra, R. Azcon, N. Ferrol and C. Azcón-Aguilar (2011). Ecological and functional roles of mycorrhizas in semi- arid ecosystems of Southeast Spain. J. Arid Enviro., 75: 1292-1301.

Calvet, C., V. Estaun, A. Camprubi, A. Hernandez-Dorrego, J. Pinochet and M.A. Moreno (2004). Aptitude for mycorrhizal root colonization in Prunus rootstocks. Scientia Horticulturae, 100: 39-49.

Corpoica, Government of Antioquia and FAO. (2007). In: "Manual of Good Agricultural Practices in the Production of Climbing Bean". FAO, Medellín, $168 \mathrm{pp}$.

Davari, M.R., S.N. Sharma and M. Mirzakhani (2012). Effect of cropping systems and crop residue incorporation on production and properties of soil in an organic agroecosystem. Biological Agriculture and Horticulture, 28: 206-222.

De Freitas, J.R., M.R. Banerjee and J.J. Germida (1997). Phosphate solubilizing rhizobacteria enhance the growth and yield but not phosphorus uptake of canola (Brassica napus L.). Biol. Fertil. Soils, 24: 358-364.

Egyptian J. Desert Res., 69, No. 1, 39-66 (2019) 
Devi, H.L., S.K. Mitra and S.C. Poi (2012). Effect of different organic and biofertilizer sources on guava (Psidium guajava L.) "Sardar". Acta Horticulturae, 959: 201-208.

Dobbelaera, S., J. Vanderleyden and Y. Okon (2003). Plant growth-promoting effects of diazotrophs in the rhizosphere. CRC Crit. Rev. Plant Sci., 22: 107-149.

Dutta, P. and S. Kundu (2012). Effect of bio-fertilizers on nutrient status and fruit quality of Himsagar mango grown in new alluvial zones of West Bengal. J. Crop Weed, 8: 72-74.

Duncan, D.B. (1955). Multiple range and multiple "F" tests. Biometrics, 11: $1-42$.

Dwivedi, D.H., R. Lata., R.B. Ram and M. Babu (2012). Effect of biofertilizer and organic manures on yield and quality of "Red Fleshed" Guava. Acta Hort., 933: 239-44.

Ebrahiem, T.A. and G.A. Mohamed (2000). Response of Balady mandarin trees growing on sandy soil to application of filter mud and farmyard manure. Assiut. J. Agri. Sci., 31 (5): 55-69.

El-Cobbia, A.M. (1999). Response of Washington Navel orange to organic fertilizer "biohomus" and cattle manure application. Alex. J. Agric. Res., 44 (2): 199-207.

El-Dissoky, R.A. (2008). Studies on the use efficiency of potassium and organic fertilizers on potatoes and its role in improving soil properties. Ph.D. Thesis, Faculty of Agriculture, Mansoura, University, Egypt.

El-Gamal, A.M. (1996). Response of tomato in new reclaimed areas to mineral nitrogen fertilizers levels and nitrogen fixing biofertilizers. Assuit J. Agric. Sci., 27: 89-99.

El-Kramany, M.F., M.K.A. Ahmed, A.A. Bahr and M.O. Kasber (2000). Utilization of biofertilization in field crop production. Egyptian J. Appl. Sci., 15: 137-149.

El-Naggar, A.M.A. (2004). Effect of organic farming on drip irrigation grapevine and soil chemical properties. Proceeding of the $2^{\text {nd }}$ International Conference of Agriculture, p. 117-128.

El-Mansi, A.A. (2007). Evaluation of organic fertilization in Thompson seedless vineyards. M.Sc. Thesis, Fac. of Agric., Mansoura Univ., Egypt.

El-Sherbeny, S.E., M.Y. Khalil, M.S. Hussein and M.S. Aly (2007). Effect of sowing date and application of foliar fertilizers on the yield and chemical composition of rue (Ruta graveolens L.) herb. Herba Polonica, 54 (1): 47-56.

Fayed, T.A. (2010a). Effect of compost tea and some antioxidants applications on leaf chemical constituents, yield and fruit quality of pomegranate. World Journal of Agricultural Sciences, 6 (4): 402-411. 
Fayed, T.A. (2010b). Optimizing yield, fruit quality and nutrition status of Roghiani olives grown in Libya using some organic extracts. Journal of Horticultural Science and Ornamental Plants, 2 (2): 63-78.

Glick, B.R. (1995). The enhancement of plant growth by free-living bacteria. Can. J. Microbiol., 41: 109-117.

Goenadi, D.H., Y. Siswanto and Y. Sugiarto (2000). Bioactivation of poorly soluble, phosphate rocks with a phosphorus-solubilizing fungus. Soil Sci. Soc. Am. J., 64: 927-932.

Gross, A., R. Arusi and A. Nejidat (2007). Assessment of extraction methods with fowl manure for the production of liquid organic fertilizers. Bioresource Technology, 99: 327-334.

Hati, K.M., K.G. Mandal, A.K. Misra, P.K. Ghosh and K.K. Bandyopadhyay (2006). Effect of inorganic fertilizer and farmyard manure on soil physical properties, root distribution, and water-use efficiency of soybean in Vertisols of central India. Bioresource Technology, 97 (16): 2182-2188.

Hause, B. and T. Fester (2005). Molecular and cell biology of arbuscular mycorrhizal symbiosis. Planta, 221: 184- 196.

Hegazy, E.S., M.R. El-Sonbaty, M.D. Ahmed and T.F. El-Sharnoby (2007). Effect of organic and bio-fertilization on vegetative growth and flowering of Picual olive trees. Wold Journal of Agricultural Science, 3(2): 210-217.

Hendawy, S.F. (2008). Comparative study of organic and mineral fertilization on Plantago arenaria plant. J. Appl. Sci. Res., 4: 500-506.

Hill, G.S. (2000). Azotobacter. In: "Encyclopedia of Microbiology". $3^{\text {rd }}$ Ed., Academic Press, New York.

Huphries, E.C. (1959). In: "Mineral Components and Ash Analysis Modern Methods of Plant Analysis". Peach K. and U.V. Tracey eds. Springer Verlag, Berlin, 1: 468 pp.

John, J.K. (1970). Colorimetric determination of phosphorus in soil and plant materials with ascorbic acid. Soil Sci., 109: 214-220.

Jones, J.B.J.R., B.V.E. Wolf and H.A. Mills (1991). In "Plant Analysis Handbook". Micro-Macro Publishing, Inc., Athens, GA.

Kundu, S., P. Datta, J. Mishra, K. Rashmi and B. Ghosh (2011). Influence of biofertilizer and inorganic fertilizer in pruned mango orchard cv. Amrapali. Journal of Crop and Weed, 7: 100-103.

Lawlor, D.W. (2002). Carbon and nitrogen assimilation in relation to yield: mechanisms are the key to understanding production systems. Journal of Experimental Botany, 53 (370): 773-787.

Litterick, A.M., L.Harrier, P. Wallace, C.A. Waston and M.Wood (2004). The role of uncomposted materials, compost, manures and compost extracts in reducing pests and diseases incidence and severity in

Egyptian J. Desert Res., 69, No. 1, 39-66 (2019) 
sustainable temperate agricultural and horticultural crop production. Plant Science, 23 (6): 453-479.

Lu, W.G., Q.W. Huang and Q.R. Shen (2005). The effect of organic fertilizer and organic-inorganic fertilizer application on soil enzymes activities during watermelon growing period. Journal of Nanjing Agricultural University, 28: 68-71.

Massoud, O.N., M.M.I. Afifi, Y.S. El-Akshar and G.A.M. El-Sayed (2013). Impact of biofertilizers and humic acid on the growth and yield of Wheat grown in reclaimed sandy soil. Res. J. Agric. Bio. Sci., 9 (2): 104-113.

Miransari, M. (2010). Contribution of arbuscular mycorrhizal symbiosis to plant growth under different types of soil stress. Plant Biology, 12: 563-569.

Mohamed, S.M., T.A. Fayed, A.F. Ismail and N.A. Abdou (2010). Growth, nutrient status and yield of le-conte pear trees as influenced by some organic and biofertilizer rates compared with chemical fertilizer. Bull. Fac. Agric. Cairo Univ., 61: 17-32.

Moustafa, M.H. (2002). Studies on fertilization of Washington navel orange trees. Ph.D. Thesis, Fac. of Agric., Zagazig Univ., Egypt.

Mostafa, M.F.M., M.S.S. El. Boray, A.F. Abd El-Wahab and R.A. Barakat (2009). Effect of enriched compost tea on Washington Navel orange trees. J. Agric. Sci. Mansoura Univ., 34 (10): 10085-10094.

Mostafa, M.F.M.,E.S. El-Baz, A.F. Abd El-Wahab and Asmaa S. M. Omar (2011). Using different sources of compost tea on grapes Journal of Plant Production, Mansoura Univ., 2 (7): 935-947.

Natarajan, K. (2007). Panchagavya for plant. Proc. Nation. Conf. Glory Gomatha. S.V. Veterinary University, Tirupati, p.72-75.

Naidu, Y., S. Meon, J. Kadir and Y. Siddiqui (2010). Microbial starter for the enhancement of biological activity of compost tea. Int. J. Agric. Biol., 12 (1): 51-56.

Nautiyal, C.S. (2000). An efficient microbiological growth medium for screening phosphate solubilizing microorganisms. FEMS Microbiology Letters, 170: 265- 270.

Negi, Y.K., D. Prabha, S.K. Garg and J. Kumar (2011). Genetic diversity among cold tolerant fluorescent Pseudomonas isolates from Indian Himalayas and their characterization for bio control and plant growth promoting activities. J. Plant Growth Regul., 30: 128-143.

Page, A.L., R.H. Miller and D.R. Keeney (1982). In: "Methods of Soil Analysis". Parts 2. American Society of Agronomy, Madison, Wisconsin, USA.

Revillas, M., A. Leffrey and M.G. Patricia (2005). Urea analysis in costal waters: compression of enzymatic and direct methods. Limnol. Octeanogr. Methods, 3: 280-299.

Egyptian J. Desert Res., 69, No. 1, 39-66 (2019) 
Rivera-Cruz, M., A. Trujillo, G. Córdova, J. Kohler, F. Caravaca and A. Roldán (2008). Poultry manure and banana waste are effective biofertilizer carriers for promoting plant growth and soil sustainability in banana crops. Soil Bio. Biochem., 40: 3092-3095.

Russo, R.O. and G.P. Berlyn, (1990). The use of organic biostimulants to help low input sustainable agriculture. J. Sus. Agric., 1 (2): 9-42.

Salinas, J.R., A. Díaz, E.Y. Garza and I. Garza (2005). Effects of tillage and biofertilization on the soil properties affecting sustainability of the dry bean production. Food Science and Technology, 5: 30-34.

Sambrook, J. and D. Russel (2001). In: "Molecular Cloning: A laboratory Manual". Cold Spring Harbor Laboratory Press, Cold Spring Harbor, NY, USA.

Sarhan, T. Z. (2008). Effect of biological fertilizers, animal residues, and urea on growth and yield of potato plant c.v. Desiree (Solanum tuberosom L.). Ph.D. Thesis, Horticulture Science and Landscape Design (Vegetable). University of Mosul, College of Agriculture and Forestry, Iraq.

Sau, S., P. Mandal, T. Sarkar, K. Das and P. Datta (2017). Influence of biofertilizer and liquid organic manures on growth, fruit quality and leaf mineral content of mango cv. Himsagar Journal of Crop and Weed, 13 (1): 132-136.

Sefan, R.F. (2009). Effect of adding some organic wastes on yield and berry quality of King Ruby grapevines. Ph.D. Thesis, Fac. of Agric., Mansoura University, Egypt.

Stefan, M., N. Munteanu and M. Mihasan (2013). Application of plant growth promoting rhizobacteria to runner bean increases seed carbohydrate and protein yield. Annals of the "Alexandru Ioan Cuza University" Section II. a Genetics and Molecular Biology, 14 (1): 29-37.

Schmitz, J. (2002). In: "Compost Tea Work on Center Pivot Farm". Capitol Press, 29: p. 20.

Soliman, A.S., E.M. Morsy and O.N. Massoud (2015). Tolerance of biofertilized Delonix regia seedling to irrigation intervals. J. Hort. For., 7 (3): 73-83.

Sun, R.L., B.Q. Zhao and L.S. Zhu (2003). Effects of long-term fertilization on soil enzyme activities and its role in adjusting- controlling soil fertility. Plant Nutrition and Fertilizer Science 9: 406-410.

Tatini, M., P.A.L. Bertoni, and M.L. Traversi (1991). Effect of humic acids on growth and biomass portioning of container-grown olive plants. Acta Hort., 294: 75-80.

Thies, J.E. (2008). Molecular methods for studying microbial ecology in the soil and rhizosphere. Molecular Mechanisms of Plant and Microbe Coexistence. Soil Biology, 15: 411-436.

Vivas, A., A. Marulanda, J.M. Ruiz-Lozano, J.M. Barea and R. Azcon (2003). Influence of Bacillus sp. on physiological activities of two arbuscular

Egyptian J. Desert Res., 69, No. 1, 39-66 (2019) 
mycorrhizal fungi and on plant responses to PEG-induced drought stress. Mycorrhiza, 13: 249-256.

Von-Bennewitz, E. and J. Hlusek (2006). Effect of the application of two biopreparations on the nutritional status, vegetative and generative behaviour of Jonagold apple trees. Acta Horticulturae, 721: 129-136.

Weisburg, W.G., S.M. Barns, D.A. Pelletier and D.J. Lane (1991). 16S ribosomal DNA amplification for phylogenetic study. J. Bacteriol., 173: 697-703.

Yadav, E., D.V. Pathak, S.K. Sharma, M. Kumar and P.K. Sharma (2007). Isolation and characterization of mutants of Pseudomonas maltophila PM-4 altered in chitinolytic activity and antagonistic activity against root rot pathogens of clusterbean (Cyamopsis tetragonoloba). Indian Journal of Microbiology, 47: 64-71.

Zahir, Z.A., M. Arshad and W.T. Frankenberger, (2004). Plant growth promoting rhizobacteria: Applications and perspectives in agriculture. Adv. Agron., 81: 97-168.

Zhao, L., M. Zhihong, Y. Luan, A. Lu, J. Wang and L. Pan (2011). Molecular methods of studying microbial diversity in soil environments. Computer and Computing Technologies in Agriculture, IV: 83-89. 


\section{إستجابة أثجار المانجو للتسيمد العضوي والحيوي في شمال سيناء}

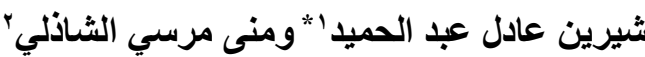

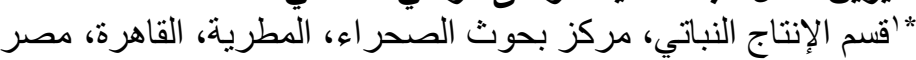

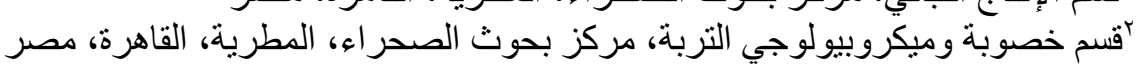

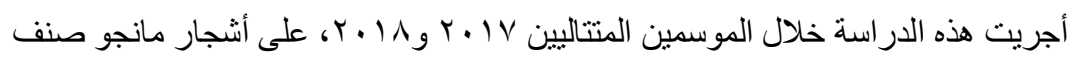

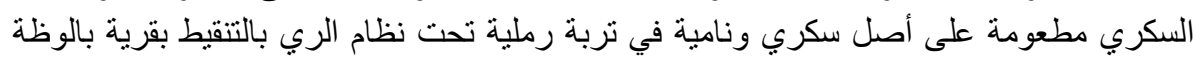

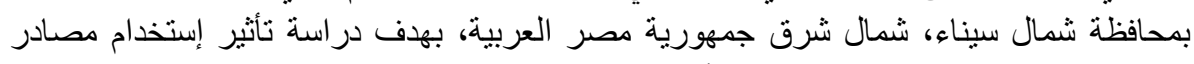

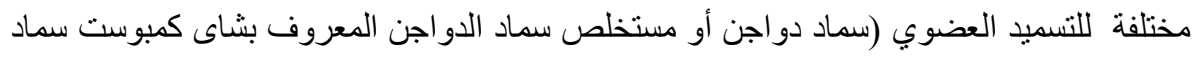

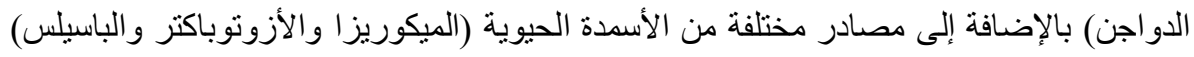

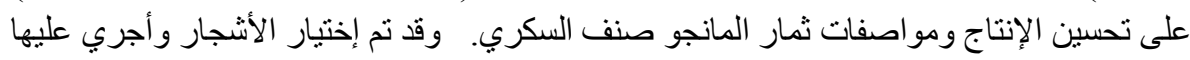

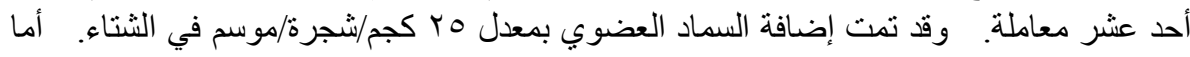

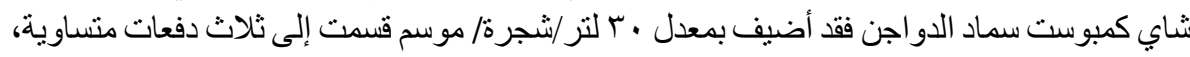

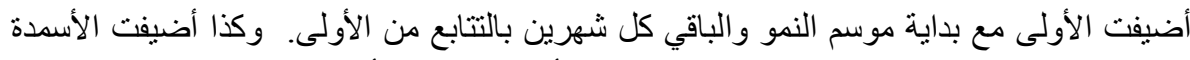

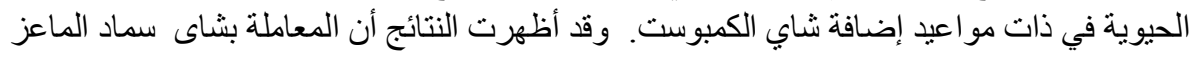

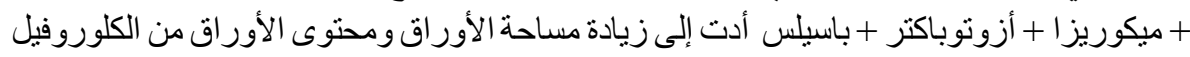

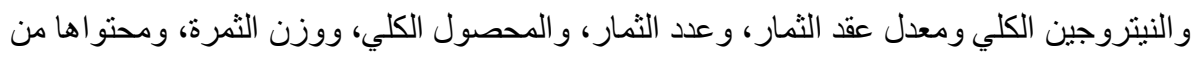

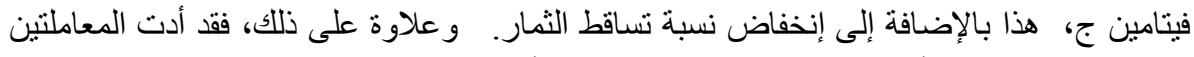

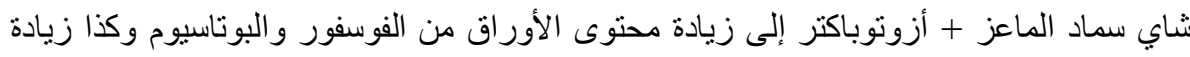

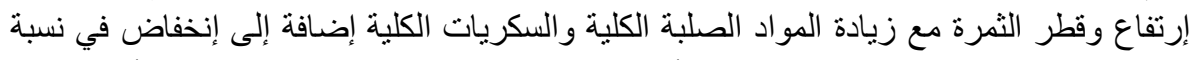

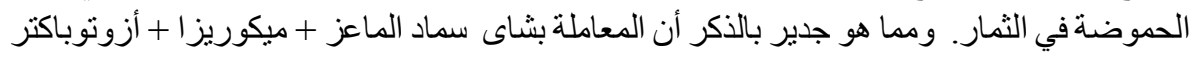

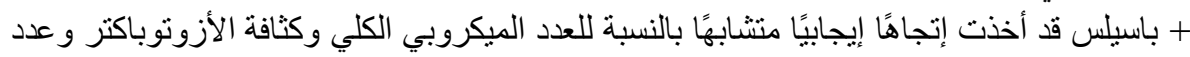

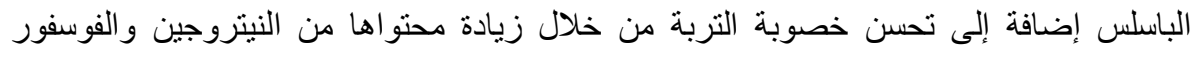

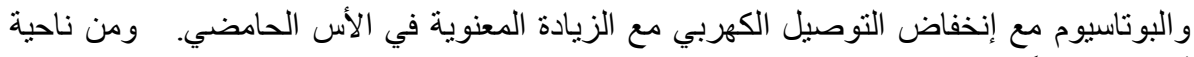

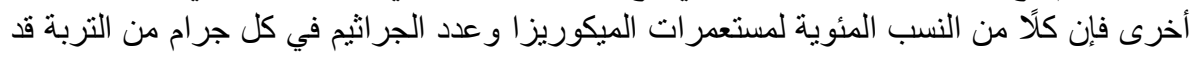

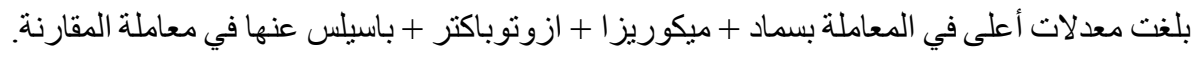

Egyptian J. Desert Res., 69, No. 1, 39-66 (2019) 